University of Tennessee College of Law

Legal Scholarship Repository: A Service of the Joel A. Katz Law Library

UTK Law Faculty Publications

$1-2010$

Against Civil Gideon (and for Pro Se Court Reform)

Benjamin H. Barton

Follow this and additional works at: https://ir.law.utk.edu/utklaw_facpubs

Part of the Law Commons 


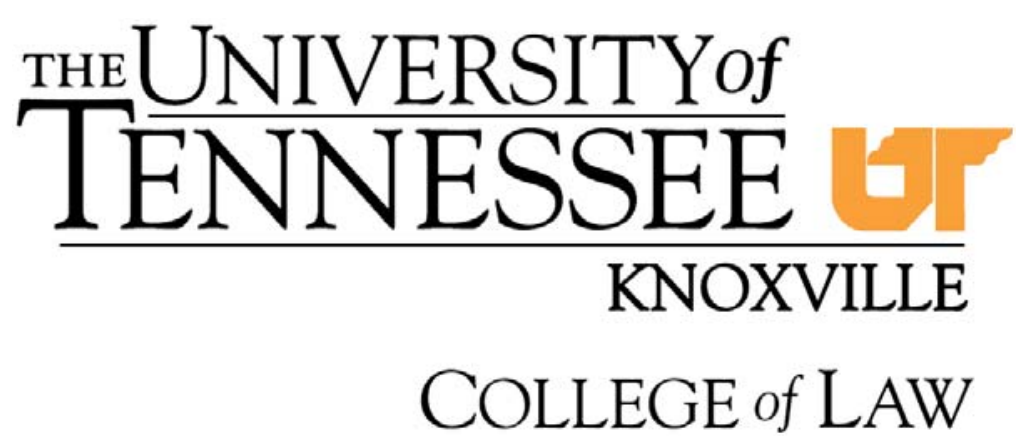

Legal Studies Research Paper Series

Research Paper \#93

February 2010

\section{Against Civil Gideon (and for Pro Se Court Reform)}

Do not cite without author's permission

Copyright (C) 2010

Benjamin H. Barton

This paper can be downloaded without charge from the Social Science Research Network Electronic library at:

http://ssrn.com/abstract=1540763 


\title{
Against Civil Gideon (and for Pro Se Court Reform)
}

\author{
Benjamin H. Barton ${ }^{1}$
}

"Civil Gideon" is a short hand name for a concept that has been the white whale of American poverty law for the last 40 years - a constitutional civil guarantee to a lawyer to match the criminal guarantee from Gideon v. Wainright. ${ }^{2}$ This Article argues that the pursuit of civil Gideon is an error logistically and jurisprudentially and advocates an alternate route for ameliorating the execrable state of pro se litigation for the poor in this country: pro se court reform. ${ }^{3}$

This Article and the civil Gideon advocates agree on one key point. The current treatment of persons too poor to afford counsel in America's civil courts is an embarrassment and a serious and growing problem. Despite this common

\footnotetext{
1 Director of Clinical Programs and Associate Professor of Law, University of Tennessee College of Law. B.A. 1991, Haverford College; J.D. 1996, University of Michigan. The author gives special thanks to Indya Kincannon, Alex Long, Mae Quinn, Doug Blaze, Charles Wolfram, Jeff Hirsch, Jennifer Hendricks, Brannon Denning, Glenn Reynolds, the participants of the 2009 SEALS Conference and the Honorable Diana Gribbon Motz.

2 Gideon v. Wainright, 372 U.S. 335, 345 (1963) guaranteed a right to appointed counsel in felony cases in federal and state cases by applying the Sixth Amendment's right to counsel to the states under the due process clause. Johnson v. Zerbst, 304 U.S. 458 (1938) created the Sixth Amendment right to a lawyer in federal felony cases. Argersinger v. Hamlin , 407 U.S. 25, 37 (1972) extended the right to counsel from Gideon and Zerbst to misdemeanors if the defendant was to face any time in jail.

Note that the civil Gideon movement actually encompasses reform efforts through both legislation and litigation. See The Legal Intelligencer Blog, Civil Gideon Movement Looks to Expand Right to Publicly Provided Legal Counsel, http://thelegalintelligencer.wordpress.com/2008/04/15/civilgideon-movement-looks-to-expand-right-to-publicly-provided-legal-counsel/ (last visited October 15, 2009). This article focuses its critique on a court-ordered civil Gideon. For reasons that will become clear, legislative civil Gideon is also inferior to pro se court reform, but is less problematic than court-mandated change, because at least it would be a result of the legislative process rather than court ordered.

${ }^{3}$ When this Article refers to "pro se court reform," that phrase means a rethinking and overhaul of courts that feature a regularized majority (or at least plurality) of pro se matters. Depending on the jurisdiction and demographics, common pro se courts include specialty courts that handle child support, child custody, domestic abuse/protective orders, landlord-tenant courts, small claims courts, and divorce courts. See Richard Zorza, The Disconnect Between the Requirements of Judicial Neutrality and Those of the Appearance of Neutrality When Parties Appear Pro Se: Causes, Solutions, Recommendations, and Implications, 17 GEO. J. LEGAL ETHICS 423, 423 n.1 (2004) (listing statistics on some majority pro se courts).
} 
ground, three key difficulties led to this Article. First, Gideon itself has largely proven a disappointment. Between overworked and underfunded lawyers and a loose standard for ineffective assistance of counsel there is little in indigent criminal defense that makes one think that a guarantee of civil counsel will work very well. Second, focusing our attention on pro se court reform is a much, much more promising and likely palliative to the legal problems of the poor.

Lastly, and most importantly, civil Gideon is a deeply conservative and backward looking solution to this problem, while pro se court reform has the potential to do more than just help the poor. It has the potential to radically reshape our justice system in ways that assist everyone. At the end of this Article I describe a science fiction thought experiment: imagine a world where the courts that deal with the poor are so simple, efficient, transparent and pleasant that for once the justice system of the poor was the envy of the rich. Pro se court reform actually offers this possibility.

If civil Gideon were merely a mildly bad idea, the division among poverty lawyers and community advocates on this issue would be of limited import. ${ }^{4}{ }^{4}$ The

\footnotetext{
${ }^{4}$ Poverty advocates fall into three general categories. Many poverty advocates are focusing the bulk of their energy on civil Gideon, see, e.g. law review symposia cited in note _; National Coalition for a Civil Right to Counsel, http://www.civilrighttocounsel.org/ (last visited December 11, 2009); Brennan Center for Justice, Civil Right to Counsel, http://www.brennancenter.org/content/section/category/civil right to counsel (last visited December 11, 2009). Others basically advocate for both approaches, see, e.g., DEBORAH L. RHODE, ACCESS TO JUSTICE 7-10, 14-16 (2004). For example Russell Engler has written advocating for both civil Gideon and pro se court reform. See Russell Engler, Shaping A Context-Based Civil Gideon from the Dynamics of Social Change, 15 TEMP. PoL. \& CIV. RTS. L. REv. 697 (2006) (advocating for civil Gideon); Russell Engler, And Justice for All--Including the Unrepresented Poor: Revisiting the Roles of the Judges, Mediators, and Clerks, 67 FoRDHAM L. REv. 1987 (1999)(advocating pro se court reform). Often pro se assistance or court reform are treated as stopgap measures. See, e.g., Mary Helen McNeal, Having One Oar or Being Without a Boat: Reflections on the Fordham Recommendations an Limited Legal Assistance, 67 FoRDHAM L. REv. 2617 (1999). Lastly, some have advocated solely for pro se court reform. See Russell G. Pearce, Redressing Inequality in the Market for Justice: Why Access To Lawyers
} 
fact that civil Gideon is a bad idea and saps energy and resources from a better, more workable solution, however, necessitates an effort to convince others to join the pro se court reform movement. ${ }^{5}$

Nevertheless, bar associations, academics and poverty lawyers are working harder on civil Gideon than ever. In 2006, the ABA House of Delegates unanimously approved a report calling for a national civil Gideon to "provide legal counsel as a matter of right at public expense to low income persons in those categories of adversarial proceedings where basic human needs are at stake, such as those involving shelter, sustenance, safety, health or child custody."6 There has likewise been an uptick of favorable scholarly attention, including at least four recent law review symposia pushing for civil Gideon. ${ }^{7}$ Public interest lawyers have filed recent cases and formed civil Gideon working groups. ${ }^{8}$

Three caveats before the argument begins in earnest. First, while this Article is quite critical of civil Gideon, no disrespect whatsoever is meant to its many

Will Never Solve the Problem and Why Rethinking the Role of Judges Will Help, 73 FoRDHAM L. REv. 969, 970 (2004). This is the first Article to comprehensively contrast the strengths and weaknesses of both approaches.

5 On a personal note, I may seem a somewhat unusual opponent to civil Gideon, as I have spent the bulk of my legal career teaching students and representing the indigent, both as appointed criminal counsel and offering free civil legal services. Nevertheless, the longer I do this work the more strongly I feel that civil Gideon is not the answer.

${ }^{6}$ American Bar Association, Civil Gideon Resolution, http://www.abanet.org/legalservices/sclaid/downloads/06A112A.pdf (last visited December 11, 2009).

7 Symposium, Civil Gideon in New York, 25 Tuoro L. Rev. 1 (2009); Symposium, A Right to Counsel in Civil Cases: Civil Gideon in Maryland \& Beyond, 37 U. BALT. L. Rev. 1 (2007); Symposium, Edward V. Sparer Symposium Civil Gideon: Creating a Constitutional Right to Counsel in the Civil Context, 15 TemP. Pol. \& Civ. RTS. L. Rev. 501 (2006); Clearinghouse Rev. J. Poverty LaW \& Policy, (July-Aug. 2006) (dedicating entire issue to "civil Gideon" efforts).

${ }^{8}$ For example, a consortium of lawyers led by the Public Justice Center filed a recent case in Maryland arguing for a civil Gideon right. See Public Justice Center, Civil Gideon, http://www.publicjustice.org/current-focusarea/index.cfm?subpageid=36\&gclid=CNHml4PxzZwCFRqdnAod6hPHLA. For a broader umbrella organization, see National Coalition for a Civil Right to Counsel, http://www.civilrighttocounsel.org/. 
proponents. As a general rule any focus on the problems of the poor is welcome and the civil Gideon supporters have their hearts in the right place. Second, part of the argument is a comparison between the lofty rhetoric and great promise of Gideon and the sad reality of our current system of indigent defense. This Article does not argue that Gideon itself is wrong or should be overturned; rather the focus is on the deeply flawed implementation, not Gideon itself. ${ }^{9}$ Last, this article includes some rather distressing facts, figures and anecdotes concerning public defenders and appointed counsel for the indigent. There are many, many excellent criminal defense lawyers working representing the poor all over the country and I have had the pleasure of meeting and working with some of them over my career, so nothing stated herein should be seen as an indictment of all criminal defense lawyers or public defenders.

It is fair to indict the system as a whole, however. System-wide the view is beyond disturbing. It is bad enough that any civil Gideon advocate should think twice before importing a broken criminal system into our civil courts. As written, Gideon is an iconic case that makes an important statement about the nature of the criminal process in the United States. Yet as applied Gideon has hardly guaranteed equal access to the courts for the poor. To the contrary, two factors have made Gideon's promise illusory indeed: the reticence of courts to set funding levels or

\footnotetext{
9 This article does argue, however, that every extension of Gideon weakens the original case and leads inevitably to a disintegration of a great case's promise.
} 
limit caseloads for Gideon's guaranteed counsel and the galling laxity of the Court's definition of the ineffective assistance of counsel..$^{10}$

In fact, there is an argument to be made that Gideon has worked out great for everyone in the system except criminal defendants. The legal profession won because a massive new source of guaranteed business was opened. ${ }^{11}$ Judges won because lawyers, in comparison to pro se litigants, make every judge's job easier. ${ }^{12}$ Society wins because everyone gets to feel better about guaranteeing defendants a lawyer. The psychological value of Gideon - that everyone can rest easy knowing that lawyers are theoretically ensuring that the system works for rich and poor alike - should not be underestimated. ${ }^{13}$ The double bonus is that system-wide the lawyers are so underpaid and overburdened that in most jurisdictions they are unable to put up much of a fight, so society gets the appearance of fairness without a high rate of acquittals or actual trials.

\footnotetext{
10 As a general rule courts have declined to order set funding levels for indigent defense or to cap case loads. See Adam M. Gershowitz, Raising the Roof: A Default Rule for Indigent Defense, 40 ConN. L. REV. 85, 88-89 (2007). Strickland v. Washington, 466 U.S. 668 (1984) is the case that set the current lax standard for ineffective assistance of counsel. Strickland is discussed at length infra notes _ and accompanying text.

11 The big prize was actually the guarantee of misdemeanor counsel in Argesinger v. Hamlin, 407 U.S. 25 (1972), because many states already guaranteed counsel in felony cases already at the time of Gideon. See Anthony LeWIS, GiDEOn's TRUMPET 144-48 (1964) (noting that 22 states joined an amicus brief in favor of appointing counsel in felony cases). By contrast, neither the federal government nor the vast majority of states provided counsel for misdemeanor prosecutions that might result in jail time. See infra note _. Argesinger itself actually includes a lengthy discussion of the additional lawyers that would be needed to staff its new guarantee of counsel. Argesinger, 407 U.S. at 37 n. 7 and 39.

12 This statement of Judge Robert Sweet in favor of civil Gideon is typical: "every trial judge knows ... the task of determining the correct legal outcome is rendered almost impossible without effective counsel." Robert W. Sweet, Civil Gideon and Confidence in a Just Society, 17 YALE L. \& PoL'Y Rev. 503, 505 (1998).

13 Judges also share this psychological salve. Any judge who regularly hears criminal trials is aware that the system has some serious flaws. Nevertheless, the appearance of a lawyer on each side of the case allows the judge to sit as a neutral arbiter rather than a culpable participant.
} 
Moreover, Strickland v. Washington set the standards for ineffective assistance of counsel so low ${ }^{14}$ that sleeping lawyers have been found effective. ${ }^{15}$ So while Gideon guarantees a robust right to counsel, Strickland and its progeny have powerfully diluted the content of that guarantee.

If civil Gideon became a reality it is extremely unlikely that civil lawyers would be better supported. Courts would likely not require limits on caseloads or increased expenditures on a guaranteed right to civil counsel. Nor would civil plaintiffs be guaranteed a competent lawyer with time to investigate, research and try their cases. To the contrary, if the absolutely critical rights theoretically protected by Gideon can be so watered down, a civil Gideon would likely fare much worse. ${ }^{16}$ The government's long-term treatment (read starvation) of civil legal aid societies also does not make civil Gideon look particularly promising. ${ }^{17}$

Civil Gideon is also very unlikely to occur. The Supreme Court chose not to extend Gideon to termination of parental rights cases in Lassiter v. Department of Social Services of Durham County. ${ }^{18}$ This was a brutal defeat for civil Gideon, because

\footnotetext{
${ }_{14}$ In Strickland, 466 U.S. at 687, the Supreme Court created a two-part test for determining ineffective assistance of counsel: the defendant must demonstrate (1) that counsel's performance fell below the standard of a reasonably competent practitioner, and (2) that the defendant was prejudiced by that sub-standard performance. The holes in this standard are discussed in greater detail infra notes __ and accompanying text.

15 For example, a Texas Appellate Court held that a sleeping lawyer's naps might have been a "strategic move" because "the jury might have sympathy for appellant because of" the naps. McFarland v. State, 928 S.W. 2d 482, 506 n.20 (Tex. Crim. App. 1996).

16 Some of the worst stories of the betrayal of Gideon's promise come from death penalty defenses. See, e.g., Stephen B. Bright, Counsel for the Poor: The Death Sentence Not for the Worst Crime but for the Worst Lawyer, 103 YALE L.J. 1835, 1836 (1994). If courts and legislatures have been disinterested in ensuring that capital defenders are well funded and trained, how will landlord/tenant defense fare?

17 Funding for legal aid services has been drastically cut over the past two decades. See SuSAN R. Martyn \& LaWrence J. Fox, Traversing the Ethical Minefield: Problems, LaW, and Professional RESPONSIBILITY 70-71 (2004).

${ }^{18}$ Lassiter v. Department of Social Services of Durham County, 452 U.S. 18 (1981).
} 
a termination of parental rights case presents the closest possible civil analogy to Gideon that does not involve imprisonment: it dealt with a liberty interest (the right to keep one's children) that the Court has repeatedly credited as powerful, as well as coercive state action, the State of North Carolina itself sought to take the Mother's children. No state or federal court since has recognized a broad civil right to counsel since the loss in Lassiter. ${ }^{19}$ Moreover, the current fiscal situation makes this an awkward time to ask a court to guarantee an expensive new constitutional right. There are serious jurisprudential concerns to extending Gideon. Among the cases that made up the due process revolution of the 1960s and early 1970s Gideon and its progeny were among the more aggressive "living constitution" cases. As a historical matter neither the Sixth Amendment nor the Fourteenth Amendment were meant to provide a government paid lawyer to criminal defendants. ${ }^{20}$ The Sixth Amendment's guarantee that a criminal defendant shall "have the assistance of counsel for his defense"21 only guaranteed the right to hire a lawyer, not the right to have the government pay for a lawyer. ${ }^{22}$ Likewise, given the extreme rarity of appointed counsel and the trend towards deprofessionalizing the legal profession at

\footnotetext{
19 See Jason Boblick, A Consumer Protection Act?: Infringement of the Consumer Debtor's Due Process Rights Under the Bankruptcy Abuse Prevention and Consumer Protection Act of 2005, 40 ARIZ. ST. L.J. 713, 735 \& n. 167 (2008). There have beensporadic, quite limited applications, see Martha F. Davis, In the Interests of Justice: Human Rights and the Right to Counsel in Civil Cases, 25 Touro L. REv. 147, 154 (2009), but nothing like the broad, national right that civil Gideon advocates are hoping for.

20 See infra notes _ and accompanying text.

21 U.S. ConsT. amend. VI.

22 See infra notes _ and accompanying text.
} 
the time of the passage of the Fourteenth Amendment, ${ }^{23}$ it is highly unlikely that the Due Process Clause was meant to guarantee appointed counsel. ${ }^{24}$

Nonetheless, Gideon is a little bit like Brown v. Board of Education. ${ }^{25}$ It may not have been consistent with the original understanding of the Constitution, but it is hard to argue in retrospect that it was not absolutely the right decision. Gideon certainly struck a chord when it held that "reason and reflection require us to recognize that in our adversary system of criminal justice, any person haled into court, who is too poor to hire a lawyer, cannot be assured a fair trial unless counsel is provided for him. This seems to us to be an obvious truth." ${ }^{26}$ Nevertheless, every new extension of Gideon takes it a step beyond the point where it is "an obvious truth" that constitutional fairness requires a new guarantee of counsel and runs the risk of replacing legislative funding priorities with those of judges. Extending the right to counsel too far could threaten the legitimacy of Gideon itself. In fact, some recent commentators have argued that the best way to protect and enforce Gideon is to roll back its extension to misdemeanor cases in Argesinger v. Hamlin. ${ }^{27}$ In fact, the broadening of Gideon to include misdemeanors, juvenile cases and other less serious types of offenses alone may have led to Gideon's destruction. Courts may have defended a right limited to felonies more jealously or at least recognized that more work was necessary on those cases then was being provided.

\footnotetext{
23 See infra notes _ and accompanying text.

${ }^{24}$ Note that since the early- $20^{\text {th }}$ century the Due Process Clause has generally been read to reflect a contemporary analysis of "fundamental fairness" rather than any original intent. See infra notes and accompanying text.

25 Brown v. Bd. of Educ. of Topeka, 347 U.S. 483 (1954).

26 Gideon, 372 U.S. at 344.

27 Erica Hashimoto, The Price of Misdemeanor Representation, 49 WM. \& MARY L. REv. 461 (2007).
} 
There are also particular reasons to be concerned in an area where judges are requiring the appointment of lawyers. One might question whether the answer to the problems of the poor are really best solved by more lawyers or more due process. Stated flatly, there are many reasons for advocates for the poor to worry when courts or bar associations announce an intention to assist the poor. The implementation of Gideon alone should offer a hint as to how these things work out in the long run. In Gideon, and other due process cases, the Court has often followed up high-minded rhetoric with a shameful lack of substance. ${ }^{28}$ At a certain point courts are no longer to blame and advocates for the poor must take some responsibility. Like Charlie Brown trying to kick Lucy's football, it may be time to try a different game.

Lastly, there is a cheaper, less constitutionally troubling and more likely solution: an overhaul of the courts that handle the bulk of the nation's pro se matters would go a long way towards reaching the aims of civil Gideon. As it stands now most courts are not set up to cope with a substantial pro se docket. Clerks are instructed not to give "legal advice" to pro se litigants. ${ }^{29}$ In many courts no one explains to pro se litigants what papers need to be filed, what needs to be argued in court or even how the process is supposed to operate..$^{30}$ In many courts judges do not consider it their responsibility to ameliorate any of this. ${ }^{31}$ Often very little effort

\footnotetext{
${ }^{28}$ For a fuller discussion, see infra notes _ and accompanying text.

${ }^{29}$ Russell Engler, And Justice for All - Including the Unrepresented Poor: Revisiting the Roles of the Judges, Mediators, and Clerks, 67 FordHAM L. REv. 1987, 1987-88 (1999).

30 Deborah L. Rhode, Legal Ethics in an Adversary System: The Persistent Questions, 34 HofsTRA L. Rev. 641,653 (noting that "a majority of surveyed courts have no formal pro se assistance services"). 31 Cf. Robert E. KEETON, Judging In The AMERICAN LEGAL SySTEM 172 (1999) (spending only three paragraphs of an entire book about the process of judging on dealing with pro se litigants).
} 
has been made to streamline or simplify either the law or the procedure in the courts where much unrepresented poverty work occurs. ${ }^{32}$

If a systematic effort were made to simplify the law and procedure in courts with large pro se dockets it could improve outcomes in those courts and do more for the poor than a guarantee of counsel, all at less cost. Too often access to justice only means access to lawyers. ${ }^{33}$ Rather than seeing the plight of the poor as an opportunity to fund more lawyers, we should see it as an opportunity to make American law simpler, fairer and more affordable. If courts with substantial pro se dockets were actually able to reform, the justice system for the poor would, for once, be the envy of the rich.

This fact alone (that better pro se courts would expose how unnecessary lawyers are in many cases) helps explain why pro se reform has been so slow to occur and why it may actually be no more likely than civil Gideon. For example, the Tennessee Supreme Court has spearheaded a statewide effort to address the hideous problems poor Tennesseans who cannot afford counsel face when seeking a divorce. ${ }^{34}$ Many of the more aggressive reforms were dead on arrival - the divorce bar was not going to stand for any changes that threatened their grip on middle and upper class divorces. ${ }^{35}$ Nevertheless, the flood of pro se cases in some courts is such that reform is happening all over the country somewhat under the radar. A unified

32 See RHodE, supra note _ at 14-16.

33 Cf. Deborah Rhode, Access to Justice: Connecting Principles to Practice, 17 Geo. J. Legal ETHICs 369, 399 (2004) ("The bar's debates about access to justice have traditionally assumed that the main problem is inadequate access to lawyers and that the solution is to make their services more broadly available.").

34 See Letter from Carl Pierce, Chairman, Tennessee Supreme Court Task Force on the Study of SelfRepresented Litigant Issues in Tennessee, to Marcy Easton, President, Tennessee Bar Association (July 30, 2007), http://www.tba.org/tbatoday/news/2007/prosedivorce_letter_090707.pdf

35 Email from Carl Pierce (September 12, 2009, 14:24 EST) (on file with author). 
push by poverty lawyers and other advocates could transform these courts and in the process the lives of the many of the poor.

The Article proceeds as follows. Part I lays out the Supreme Court case law on free, appointed counsel from Gideon to Lassiter. Part II discusses the status of civil Gideon efforts post-Lassiter. Part III argues that extending Gideon to civil cases presents a number of logistical and constitutional concerns. Part IV concludes that there is a batter way to address the needs of the poor - a comprehensive effort to reform those courts that have a large pro se docket.

\section{From Gideon to Lassiter}

In a series of famous 1960s cases the Warren Court of the 1960s launched a due process revolution in criminal procedure, guaranteeing a series of new rights to criminal defendants. Gideon v. Wainright was among the earliest of these cases and it remains one of the most enduring and influential.

\section{A. Pre-Gideon}

The journey to Gideon began in 1932 with Powell v. Alabama. ${ }^{36}$ Interestingly, Powell was not a Sixth Amendment right to counsel case, it dealt with Fourteenth Amendment Due Process. ${ }^{37}$ Powell dealt with the trial of nine black defendants accused (with very little supporting evidence) of raping two white women on a train passing through Alabama. The trial was an obvious sham. It was held only days after the alleged crime before an all white jury. The defendants were not allowed to

36 Powell, 287 U.S. 45 (1932).

37 Id. at 71. 
choose their counsel and the trial court appointed two attorneys on the eve of trial, with no time or incentive to investigate or prepare a defense. ${ }^{38}$

The Supreme Court concluded that the "defendants were not accorded the right of counsel in any substantial sense." ${ }^{39}$ Nevertheless, the Supreme Court faced two substantial barriers to overturning the case. First, the Alabama Constitution stated a right to assistance of counsel, an Alabama Statute required appointed counsel in capital cases and the court had actually appointed lawyers to represent the defendants. ${ }^{40}$ So the case involved more than just a right to counsel, because counsel was actually appointed it required a finding of a right to competent counsel.

Second, the Sixth Amendment did not apply to the States at the time and it was unclear whether the Fourteenth Amendment could guarantee a right to counsel in state courts at all. This was especially so in light of Hurtado v. California, ${ }^{41}$ which refused to require a grand jury indictment in the States under the Due Process Clause because "if it had been the purpose of [the Fourteenth] Amendment to perpetuate the institution of the grand jury in the states, it would have embodied, as did the Fifth Amendment, an express declaration to that effect." ${ }^{22}$ This reasoning obviously applied to the Sixth Amendment's right to counsel as well.

The Court avoided these problems in two ways. First, it mounted a passionate defense of the critical role of effective criminal defense counsel:

The right to be heard would be, in many cases, of little avail if it did not comprehend the right to be heard by counsel. Even the intelligent and

\footnotetext{
38 Dan T. Carter, Scottsboro: A Tragedy of the American South (2d ed. 1979) 11-20.

39 Powell, 287 U.S. at 58.

40 Id. at 59-60.

41 Hurtado, 110 U.S. 516 (1884).

42 Powell, 287 U.S. at 66.
} 
educated layman has small and sometimes no skill in the science of law. If charged with crime, he is incapable, generally, of determining for himself whether the indictment is good or bad. He is unfamiliar with the rules of evidence. Left without the aid of counsel he may be put on trial without a proper charge, and convicted upon incompetent evidence, or evidence irrelevant to the issue or otherwise inadmissible. He lacks both the skill and knowledge adequately to prepare his defense, even though he have a perfect one. He requires the guiding hand of counsel at every step in the proceedings against him. Without it, though he be not guilty, he faces the danger of conviction because he does not know how to establish his innocence. If that be true of men of intelligence, how much more true is it of the ignorant and illiterate, or those of feeble intellect. If in any case, civil or criminal, a state or federal court were arbitrarily to refuse to hear a party by counsel, employed by and appearing for him, it reasonably may not be doubted that such a refusal would be a denial of a hearing, and, therefore, of due process in the constitutional sense. ${ }^{43}$

Second, despite the far reaching logical ramifications of the above language the Court limited its holding quite narrowly to the facts at issue: appointment of effective counsel is required "in a capital case, where the defendant is unable to employ counsel, and is incapable adequately of making his own defense because of ignorance, feeble-mindedness, illiteracy, or the like."44

Six years after Powell the Court held for the first time that the Sixth Amendment right to counsel guaranteed appointed counsel in federal courts in Johnson v. Zerbst. ${ }^{45}$ The Court quoted at length from the language quoted from Powell above and noted the Sixth Amendment "embodies a realistic recognition of the obvious truth that the average defendant does not have the professional legal skill to protect himself when brought before a tribunal with power to take his life or liberty, wherein the prosecution is presented by experienced and learned

43 Id. at 68-69.

${ }^{44}$ Id. at 71 .

45 Johnson v. Zerbst, 304 U.S. 458 (1938). 
counsel." ${ }^{46}$ As a result, after 1938 criminal defendants in the federal system had a right to appointed counsel under the Sixth Amendment.

In 1942 the Court turned to the application of the Sixth Amendment in state courts in Betts v. Brady ${ }^{47}$ and held that the "Sixth Amendment of the national Constitution applies only to trials in federal courts." ${ }^{48}$ The Court did allow that the denial of an appointed lawyer in state court could "constitute a denial of fundamental fairness" on a case-by-case basis, depending on "the totality of the facts." ${ }^{49}$

The Court went through an exhaustive history of the right to counsel in the colonies and states from before the American Revolution up to the current practice in 1942. The Court noted that in the 18th and 19th centuries the appointment of counsel had been covered, if at all, as a statutory matter in the states, not constitutionally and that "the contemporary legislation" on appointment of counsel "exhibits great diversity of policy."50 The Court then concluded:

This material demonstrates that, in the great majority of the states, it has been the considered judgment of the people, their representatives and their courts that appointment of counsel is not a fundamental right, essential to a fair trial. On the contrary, the matter has generally been deemed one of legislative policy. In the light of this evidence we are unable to say that the concept of due process incorporated in the Fourteenth Amendment obligates the states, whatever may be their own views, to furnish counsel in every such case. $^{51}$

\section{B. Gideon}

46 Zerbst, 304 U.S. at 462-63.

47 Betts v. Brady, 316 U.S. 455 (1942).

48 Betts, 316 U.S. at 461.

49 Id. at 462.

50 Id. at 467-69 \& n. 20.

51 Id. at 471-72. 
Twenty-three years later in Gideon v. Wainright ${ }^{52}$ the Court overruled Betts in felony cases and incorporated the Sixth Amendment into the Due Process Clause..$^{53}$ Gideon listed the main precedents that had guaranteed a right to counsel in federal courts - Zerbst and Powell v. Alabama - as support for its decision and argued that Betts had been an "abrupt break" with these precedents. ${ }^{54}$ Nevertheless, Gideon's own discussion of Betts recognized that Betts was based upon "the constitutional, legislative, and judicial history of the states to the present date,"55 and even commentators who agree with Gideon's holding have noted that Betts more accurately described the history of the appointment of counsel in criminal cases..$^{56}$

The heart of the opinion comes not from precedent, but from the Court's eloquent defense of the need for counsel as an irreplaceable aspect of the fundamental fairness guaranteed by the Due Process Clause:

Not only these precedents but also reason and reflection require us to recognize that in our adversary system of criminal justice, any person haled into court, who is too poor to hire a lawyer, cannot be assured a fair trial unless counsel is provided for him. This seems to us to be an obvious truth. Governments, both state and federal, quite properly spend vast sums of money to establish machinery to try defendants accused of crime. Lawyers to prosecute are everywhere deemed essential to protect the public's interest in an orderly society. Similarly, there are few defendants charged with crime, few indeed, who fail to hire the best lawyers they can get to prepare and present their defenses. That government hires lawyers to prosecute and defendants who have the money hire lawyers to defend are the strongest indications of the wide-spread belief that lawyers in criminal courts are necessities, not luxuries. The right of one charged with crime to counsel may not be deemed fundamental and essential to fair trials in some countries, but

52 Gideon, 372 U.S. 335 (1963).

53 Id. at 344-45.

54 Id. at 344.

55 Id. at 340 .

56 See, e.g., David A. Strauss, On the Origin of Rules (With Apologies to Darwin): A Comment on Antonin Scalia's The Rule of Law as a Law of Rules, 75 U. CHI. L. Rev. 997, 1008-09 (2008) ("None of the preBetts cases, fairly read, really suggested an across-the-board rule requiring states to appoint counsel in all felony cases."). 
it is in ours. From the very beginning, our state and national constitutions and laws have laid great emphasis on procedural and substantive safeguards designed to assure fair trials before impartial tribunals in which every defendant stands equal before the law. This noble ideal cannot be realized if the poor man charged with crime has to face his accusers without a lawyer to assist him. ${ }^{57}$

This language, and Gideon's holding, was promising to criminal defense and poverty lawyers on a number of levels. First, it stated a very muscular interest in the fairness of court proceedings that involved the indigent. Second, it overruled a relatively new, twenty-one year old precedent. Third, it did so despite the fact that Betts was basically correct on the lack of a longstanding right to appointed counsel at common law or in the states. ${ }^{58}$ Lastly, the long, florid section quoted above includes no supporting citations, an unusual move for the Court. The willingness to use "reason and reflection" in this manner suggested that the Court would now scrutinize the criminal justice system much more closely, even if it meant discarding controlling precedent.

\section{Post-Gideon}

The language and holding of Gideon had obvious implications for civil cases and calls for Gideon's application to unrepresented indigent litigants in civil cases began almost immediately. For example, in Sandoval v. Rattikin an indigent Texas litigant argued that the Fourteenth Amendment required appointment of counsel in a property dispute (technically a trespass-to-try-title action). ${ }^{59}$ The Texas appellate

57 Gideon, 372 U.S. at 344. The Court followed this language with a long quote of "the moving words of Mr. Justice Sutherland in Powell v. Alabama" quoted above.

58 See supra notes _ and accompanying text.

59 Sandoval v. Rattikin, 395 S.W.2d 889, 893-94 (Tex. Civ. App. 1965), cert. denied, 385 U.S. 901 (1966). 
court disagreed and the Supreme Court denied certiorari. ${ }^{60}$ Likewise, a 1967 Yale Law Journal Note argued for “The Indigent's Right to Counsel in Civil Cases."61

While no court openly embraced a right to appointed civil counsel during this period, Gideon itself was extended in a series of cases that offered hope. In the cases described below the Court extended Gideon beyond felonies to misdemeanors and to quasi-criminal cases that were not strictly Sixth Amendment criminal cases.

In Argesinger v. Hamlin the Court held that the Sixth Amendment right to appointed counsel applied beyond felonies to any misdemeanor prosecution that resulted in jail time, regardless of how short that sentence might be. ${ }^{62}$ Since the liberty interests involved in some civil cases (notably deportation or termination of parental rights cases) were arguably at least as strong (and possibly stronger), Argesinger seemed a natural step towards civil Gideon.

Likewise, a series of non-Sixth Amendment cases stretched Gideon in ways that suggested that a civil right to counsel might fit. In re Gault extended Gideon to juvenile proceedings, even though juvenile proceedings were not strictly criminal in nature. ${ }^{63}$ Gault held that the nature of the right at stake - the juvenile defendant's liberty itself - was the key question in determining a right to appointed counsel

\footnotetext{
60 Sandoval, 395 S.W.2d at 893-94.

61 Note, The Indigent's Right to Counsel in Civil Cases, 76 YALE L.J. 545 (1967). Other similar works include Note, The Right to Counsel in Civil Litigation, 66 Colum. L. REV. 1322 (1966); Note, The Indigent's Right to Counsel in Civil Cases, 43 Fordham L. REv. 989 (1975); Note, The Emerging Right of Legal Assistance for the Indigent in Civil Proceedings, 9 U. MiCH. J.L. REFORM 554 (1976); Comment, Current Prospects for an Indigent's Right to Appointed Counsel and Free Transcript in Civil Litigation, 7 PAC. L.J. 149 (1976).

62 Argersinger v. Hamlin, 407 U.S. 25, 37 (1972).

63 In re Gault, 387 U.S. 1, 40-41 (1967) (extending the right to counsel to juvenile proceedings if confinement is possible).
} 
under a due process analysis, rather than whether a Sixth Amendment right was implicated. ${ }^{64}$

Taken together Gault and Argesinger seemed quite helpful to civil Gideon. Gault made clear that the due process driven right to counsel extended beyond Sixth Amendment cases and that the critical question was the nature of the right at stake. Argesinger set a relatively low bar for the seriousness needed: even the threat of a day in jail was sufficient to trigger a constitutional requirement for appointed counsel.

The subsequent cases were more of a mixed bag; none squarely foreclosed or required civil Gideon. The 1980 case of Vitek v. Jones extended the right to counsel to prisoners who were being involuntarily transferred from prison to a state mental hospital. ${ }^{65}$ Vitek held that prisoners have a due process right not to be transferred without a hearing and an appointed lawyer despite the fact that the transfer hearing was civil and not criminal in nature, based on the liberty interest at stake and the potential stigma of being found mentally ill. ${ }^{66}$ Note that Vitek is another case where the liberty interest was not confinement: when the transferred prisoner's sentence was finished a civil commitment proceeding was necessary to hold him longer in the mental hospital. ${ }^{67}$

The Court also refused to extend Gideon in several cases before Lassiter. Notably, in Gagnon v. Scarpelli and Morrissey v. Brewer the Court held that while counsel might be required in some proceedings to revoke parole or find a violation

${ }^{64}$ Gault, 387 U.S. at 39-42.

65 Vitak v. Jones, 445 U.S. 480 (1980).

66 Id. at 487-88.

67 Id. at 483-84. It is true, however, that the type of confinement was changed. 
of probation, counsel was not uniformly necessary in those types of cases. ${ }^{68}$ This holding basically applied the case-by-case analysis that had been applied between Betts and Gideon to this new area. ${ }^{69}$ The Court declined to extend Gideon to these proceedings because parolees and probationers have a lessened liberty interest and revocation of probation or parole cases are generally less formal and often do not involve a lawyer on the government's side. ${ }^{70}$ Nevertheless, Gagnon and Morrissey sat uneasily with In re Gault and Argesinger because all of the cases involved potential imprisonment as the liberty interest, but in the parole and probation cases no lawyer was required. The Court also refused to extend Argesinger and Gideon to misdemeanor prosecutions that did not result in imprisonment in Scott v. Illinois. ${ }^{71}$

The pre-Lassiter cases were thus a bit of a mess. It was certainly clear that the right to appointed counsel stretched beyond the Sixth Amendment's guarantee of counsel in criminal cases because Gault and Vitek extended the right to civil proceedings. There were a series of cases that seemed to suggest that the key protected liberty interest was freedom from imprisonment, no matter how short the

68 Gagnon v. Scarpelli, 411 U.S. 778, 789-91 (1973) (holding that counsel need not be provided in all probation revocation hearings, but should be in appropriate cases); Morrissey v. Brewer, 408 U.S. 471, 489 (1972) (not reaching the question of whether counsel must be provided in parole revocation hearings). Later courts applied Gagnon's holding on counsel to the Morrissey situation, settling that question in both revocation of parole and violation of probation cases. See Lassiter, 452 U.S. at 26.

69 See Gagnon, 411 U.S. at 788-89 ("In so concluding, we are of course aware that the case-by-case approach to the right to counsel in felony prosecutions adopted in Betts v. Brady, was later rejected in favor of a per se rule in Gideon v. Wainwright.").

70 See id. at 786-88.

${ }^{71}$ Scott v. Illinois, 440 U.S. 367, 373 (1979) (holding that the "central premise of Argersinger" was "that actual imprisonment is a penalty different in kind from fines or the mere threat of imprisonment"). There were two more pre-Lassiter cases that refused to extend Gideon. In Goss v. Lopez, 419 U.S. 565, 583 (1975), the Court refused to extend Gideon to school disciplinary hearings, because those proceedings are brief, informal, and educational in nature. In Parham v. J.R., 442 U.S. 584, 604-609 (1979) the Court refused to extend Gideon to voluntary commitment proceedings involving a minor because of the parent's role as well as the medical and informal nature of those proceedings. 
imprisonment: Gault and Argesinger appointed counsel because of potential imprisonment and Scott v. Illinois denied counsel where imprisonment was not at issue.

Vitek, Gagnon, and Morrissey, however, undercut grouping the cases according to a threat of imprisonment: Gagnon v. Scarpelli and Morrissey v. Brewer involved the threat of imprisonment (and revocation hearings often involve much longer prison terms than misdemeanor prosecutions) ${ }^{72}$ and refused automatic appointment of counsel, while Vitek allowed appointment despite the fact that no additional imprisonment was at issue (although serving the time in a mental hospital was certainly a different type of imprisonment). Thus, while there were cases that suggested that imprisonment was the key distinction, other cases suggested that courts should weigh the import of the liberty interest at stake and then decide whether fundamental fairness required appointment of a lawyer.

\section{Lassiter}

With these cases in mind, the Court turned to the idea of civil Gideon in the 1982 case of Lassiter v. Department of Social Services of Durham County. ${ }^{73}$ Lassiter dealt with the state of North Carolina's termination of parental rights case against Abby Gail Lassiter. ${ }^{74}$

In many ways Lassiter was an optimal civil Gideon case. Outside of imprisonment, the right to parent one's children is perhaps the strongest

\footnotetext{
72 Cf. Morrissey, 408 U.S. 471, 472-73 (the two petitioners faced as much as 6 or 7 additional years of imprisonment upon their parole revocation, whereas Argesinger protects misdemeanor defendants who face any threat of imprisonment, even a day).

73 Lassiter, 452 U.S. 18 (1981).

${ }^{74} \mathrm{Id}$. at 20-22.
} 
constitutional liberty interest. Lassiter itself stated the interest in quite stringent

terms:

This Court's decisions have by now made plain beyond the need for multiple citation that a parent's desire for and right to the companionship, care, custody and management of his or her children is an important interest that undeniably warrants deference and, absent a powerful countervailing interest, protection. Here the State has sought not simply to infringe upon that interest but to end it. If the State prevails, it will have worked a unique kind of deprivation. A parent's interest in the accuracy and injustice of the decision to terminate his or her parental status is, therefore a commanding one. ${ }^{75}$

Moreover, termination of parental rights involves the government itself

permanently terminating the parental relationship in a formal legal proceeding.

Thus, Lassiter presented a legal structure almost identical to Gideon: the State sought to deprive the petitioner of a critical liberty interest in a formal proceeding brought by the state's lawyers. If there was going to be a type of civil case where, like Gideon, it would be an "obvious truth" that the petitioner could not "be assured a fair trial unless counsel is provided for [her]," this was it. In this regard, the petitioners in Lassiter had a strong argument that termination of parental rights proceedings were akin to the juvenile proceedings in Gault or the transfer proceedings in Vitek. Termination proceedings were not criminal proceedings, but the liberty deprivation was so great that a quasi-criminal level of protection were appropriate. ${ }^{76}$

75 Id. at 27 (citation and quotation marks omitted).

76 Cf. Lassiter, 452 U.S. at 37 (Blackmun, J., dissenting) ("Where an individual's liberty interest assumes sufficiently weighty constitutional significance, and the State by a formal and adversarial proceeding seeks to curtail that interest, the right to counsel may be necessary to ensure fundamental fairness."). 
Nevertheless, Lassiter is one of those cases where a brief read through of the facts makes the decision itself anti-climactic. The majority opinion includes an embarrassing plethora of details (many of which are clearly irrelevant to the legal issue at hand) to make it clear to any reader that Abby Lassiter was not a fit parent for her son and that an appointed lawyer would have made no difference whatsoever. ${ }^{77}$

The facts are meant to demonstrate that Abby Lassiter was a terribly unfit mother and a dangerous criminal. Abby Lassiter's infant son William came to the attention of the Department of Social Services ("DSS") because of a complaint from Duke Pediatrics that Ms. Lassiter had not followed up with the pediatric clinic for her son's medical problems and that "they were having difficulty in locating Ms. Lassiter."78 In response to that complaint, a social worker took William from Ms. Lassiter's care and brought him to the hospital herself. William was then admitted and treated for "breathing difficulties [and] malnutrition and [because] there was a great deal of scarring that indicated that he had a severe infection that had gone untreated."79 In late-spring 1975, a Durham County District Court found that Ms. Lassiter had not provided William with proper medical care, adjudicated him a neglected child and transferred him to the custody of the Department of Social Services.

The Court goes on to paint Ms. Lassiter as almost aggressively disinterested in her child, noting that "except for one 'prearranged' visit and a chance meeting on

\footnotetext{
77 All of the facts in the next few paragraphs come from Lassiter itself. Id. at 22-28.

78 Id. at 22.

79 Id. at 21 (internal quotation marks omitted).
} 
the street, Ms. Lassiter had not seen William after he had come into the State's custody, and that neither Ms. Lassiter nor her mother had 'made any contact with the Department of Social Services regarding that child.'"80 The Court also states that Ms. Lassiter did not contest or even attend the hearing originally removing William from her custody.

Of course, the Court explains that Ms. Lassiter might have been busy during this period, since she and her mother were accused of First Degree murder in the Spring of 1976. The details of Ms. Lassiter's criminal charges are clearly not relevant to her due process rights in a termination of parental rights proceeding, but in footnote one in the very first paragraph of the opinion the Court gratuitously includes a lurid description of the crime from Ms. Lassiter's criminal appeal:

Defendant's mother told [the deceased] to 'come on.' They began to struggle and deceased fell or was knocked to the floor. Defendant's mother was beating deceased with a broom. While deceased was still on the floor and being beaten with the broom, defendant entered the apartment. She went into the kitchen and got a butcher knife. She took the knife and began stabbing the deceased who was still prostrate. The body of deceased had seven stab wounds. State v. Lassiter, No. 7614 SC1054 (June 1, 1977). ${ }^{81}$

Ms. Lassiter was sentenced to 25-40 years of imprisonment.

The Court's version of the facts also establishes that not only did Ms. Lassiter fail to request a lawyer's assistance in the termination proceedings; she was positively disinterested in the proceedings. According to the Court, Ms. Lassiter's mother paid to have a lawyer for her criminal appeal, but Ms. Lassiter did not

80 Id. at 22 .

81 Id. at 20 n. 1. 
mention the termination to that lawyer or hire another lawyer. ${ }^{82}$ Moreover, she was brought to the termination hearing at "the behest of the Department of Social Services' attorney." ${ }^{83}$ At that hearing the issue of appointed legal representation was raised "at the judge's insistence," rather than by Ms. Lassiter. ${ }^{84}$ The trial court concluded that Ms. Lassiter "had ample opportunity to seek and obtain counsel prior to the hearing of this matter, and [that] her failure to do so is without just cause." 85 Later, the Court held that in "deciding whether due process requires the appointment of counsel" a reviewing court "need not ignore a parent's plain demonstration" of disinterest in such proceedings, specifically referencing that "Ms. Lassiter had not even bothered to speak to her retained lawyer after being notified of the termination hearing." 86 The words "had not even bothered" well state the Court's feelings on Ms. Lassiter's case.

Last, the Court presents a number of facts that devastate Ms. Lassiter's main argument against termination of parental rights: that her mother (William's grandmother) should be given custody. The Court stated that the grandmother had actually reported Ms. Lassiter to DSS. The Court quoted testimony establishing that the grandmother had indicated "on a number of occasions that she was not able to take responsibility for the child" and that "people in the community and from [the grandmother]'s church" also felt that she could not handle the responsibility and

82 Id. at 21-22. The Court notes that Ms. Lassiter did not mention the termination proceedings "to any other person except, she said, to 'someone' in the prison." The details in this sentence alone well establish the Court's disdain for Ms. Lassiter. It is not enough to point out that Ms. Lassiter failed to talk to anyone about the proceedings except "someone" at the prison, the Court adds the "she said" to suggest that even that contact should be doubted as unsubstantiated testimony.

83 Id. at 21.

84 Id. at 21-22.

85 Id. at 21-22.

86 Id. at 33 . 
that William "has not seen his grandmother since [a] chance meeting in July of '76 and that was the only time." ${ }^{87}$

Worst of all, the Court makes much of the grandmother's role in the murder that led to Ms. Lassiter's incarceration. The Court includes the fact that the grandmother was also indicted for first degree murder. ${ }^{88}$ The Court points out that Ms. Lassiter's post-conviction challenge of her murder trial was partially based upon a claim that the grandmother actually committed the crime and had said "And I did it, I hope she dies." ${ }^{89}$ Nor does the Court let these facts pass without comment. During the due process analysis the Court openly mocks Ms. Lassiter's custody argument: "Ms. Lassiter's argument here that her mother should have been given custody of William is hardly consistent with her argument in the collateral attack on her murder conviction that she was innocent because her mother was guilty." 90

So, in sum, the Court's description of the case involved a convicted murderer and her accomplice seeking custody of a child neither of them had seen or shown any interest in for years. After reading these facts it is obvious that there was virtually no chance that the Supreme Court would require a retrial of this case with a lawyer. Their description of the case leaves the reader with only one question: what took the State so long?

Nevertheless, to deny Ms. Lassiter's appeal the Court still needed to place this case within its post-Gideon precedents. As noted above, this was not going to be easy. Lassiter chose to draw a bright line at imprisonment: "The pre-eminent

\footnotetext{
87 Id. at 21-22.

88 Id. at 20 n. 1.

${ }^{89} \mathrm{Id}$.

${ }^{90}$ Id. at 33 n. 8.
} 
generalization that emerges from this Court's precedents on an indigent's right to appointed counsel is that such a right has been recognized to exist only where the litigant may lose his physical liberty if he loses the litigation." ${ }^{11}$ The Court distinguished Gagnon and Morissey by noting that parolees and probationers only have a "conditional liberty" interest and "as a litigant's interest in personal liberty diminishes, so does his right to appointed counsel." ${ }^{92}$

With this generalization in mind, the Court created a "presumption that an indigent litigant has a right to appointed counsel only when, if he loses, he may be deprived of his physical liberty."93 This presumption serves as a weight "against... all the other elements in the due process decision." 94 The creation of such a presumption basically doomed Ms. Lassiter's appeal and has stood as a powerful barrier to any recognition of a civil Gideon ever since.

The "other elements in the due process decision" are the three part test from Mathews v. Eldridge: "[1] the private interests at stake, [2] the government's interest, and [3] the risk that the procedures used will lead to erroneous decisions." 95 A court "must balance these elements against each other, and then set their net weight in the scales against the presumption that there is a right to appointed counsel only where the indigent ... may lose his personal freedom." 96

The Court then applied the test to the termination of parental rights. On the first prong, the Court found that a parent has a very strong interest in maintaining

\footnotetext{
91 Id. at 25 .

92 Id. at 26.

93 Id. at 26-27.

94 Id.

95 Id. at 27 (citing Mathews v. Eldridge, 424 U.S. 319, 335 (1976)).

96 Id. at 27.
} 
their parental rights. ${ }^{97}$ On the second prong, the State shares the parental interest in what is best for the child and the importance of an accurate decision. The State's interests diverge from the parent's, however, because it wants to proceed "as economically as possible" and "wants to avoid both the expense of appointed counsel and the cost of the lengthened proceedings his presence may cause."98 0 n the last prong the Court listed the various procedural protections provided beyond the appointment of a lawyer (written notice, a hearing, etc.), but also considered the possibility of a complicated termination case involving expert or medical testimony. ${ }^{99}$

When the Court turned to balancing these factors, the actual circumstances of Ms. Lassiter led inevitably to a finding that on balance a lawyer was not necessary in her case and therefore not necessary in every termination of parental rights case. The case involved no particularly complicated law or facts. No experts testified. Ms. Lassiter had a chance to present her case and cross-examine witnesses. ${ }^{100}$ Moreover, the Court used the many unfortunate facts outlined above against the concept of civil Gideon. Ms. Lassiter was serving a lengthy prison sentence and obviously not fit to care for her son. According to her own post-conviction arguments, Ms. Lassiter's mother was likely an accomplice in the murder and she had repeatedly said she did not want the child. ${ }^{101}$ Neither Ms. Lassiter nor her mother had shown any interest in the child. Nor had Ms. Lassiter shown much

97 Id. at 27.

98 Id. at 28.

99 Id. at 28-31.

$100 \mathrm{Id}$. at 32-33.

101 Id. at 33 \& n. 8. 
interest in even attending the proceeding. ${ }^{102}$ In a contest where "fundamental fairness" was at issue the Court stacked the deck strongly against Ms. Lassiter and civil Gideon.

The denial of appointed counsel in termination of parental rights proceedings basically signaled the death knell for civil Gideon on a going forward basis. ${ }^{103}$ If the presumption against appointed counsel in non-imprisonment cases is strong enough to defeat a due process claim dealing with the state taking a citizen's children, it is hard to imagine a different scenario where appointment would be required. This is especially so where the Court admitted that the "potential costs of appointed counsel in termination proceedings" is "de minimis compared to the costs [of appointment] in all criminal actions,"104 and still refused to require appointed counsel in each case. ${ }^{105}$

\section{Post-Lassiter Civil Gideon}

Based upon Lassiter one would expect civil Gideon to hibernate for a time and this was indeed the case. From Lassiter until the mid-90s little happened on the civil Gideon front. ${ }^{106}$ Interestingly it was a judge who helped relaunch civil Gideon. On December 2, 1997, Federal District Court Judge Robert Sweet gave a speech in favor

\footnotetext{
102 Id. at 31-33.

103 See Bruce A. Boyer, Justice, Access to the Courts, and the Right to Free Counsel For Indigent Parents: The Continuing Scourge of Lassiter v. Department of Social Services of Durham, 36 LOY. U. CHI. L.J. 363, 367-72 (2005).

104 Id. at 28.

105 On this score, compare Gideon, where the practice of most states in appointing felony counsel was critical to the Court's decision, Gideon, 372 U.S. at 345, with Lassiter, which uses the fact that 33 states appoint counsel in Ms. Lassiter's circumstances as support for the fairness of its decision. Lassiter, 452 U.S. at 34.

106 See Martha F. Davis, In the Interests of Justice: Human Rights and the Right to Counsel in Civil Cases, 25 Touro L. REv. 147, 153-54 ("Until recently, the Lassiter decision had a chilling effect on domestic litigation and advocacy supporting a right to counsel in civil cases.").
} 
of what he termed a "civil Gideon." The speech was reprinted in the Yale Law and Policy Review. ${ }^{107}$

From this article forward there has been a tremendous rekindling of interest in civil Gideon. For example, just since 2006 there have been three civil Gideon law review symposium issues. ${ }^{108}$ Likewise, the $\mathrm{ABA}^{109}$ and multiple state bar

107 Robert W. Sweet, Civil Gideon and Confidence in a Just Society, 17 YALE L. \& PoL'Y REv. 503, 503 (1998). A Westlaw search in the JLR database for the term "civil Gideon" finds 132 articles, with only three mentions pre-dating Sweet's article. In fact, from this search it appears that from Lassiter until 1997 only one law review article was written about civil Gideon. See Earl F. Johnson, Jr., The Right to Counsel in Civil Cases: An International Perspective, 19 Loy. L.A. L. REv. 341 (1985).

108 Symposium, Civil Gideon in New York, 25 Tuoro L. Rev. 1 (2009); Symposium, A Right to Counsel in Civil Cases: Civil Gideon in Maryland \& Beyond, 37 U. Balt. L. Rev. 1 (2007); Symposium, Edward V. Sparer Symposium Civil Gideon: Creating a Constitutional Right to Counsel in the Civil Context, 15 TEMP. Pol. \& Civ. RTs. L. Rev. 501 (2006); Clearinghouse Rev. J. Poverty LaW \& Policy, (July-Aug. 2006) (dedicating entire issue to "civil Gideon" laws). There was also a recent civil Gideon conference cosponsored by the ABA and the Massachusetts Bar Association. See Kelsey Sadoff, Civil Gideon Symposium Mobilizes Legal Community Behind Equal Justice in Law, LAWYERS JournaL, Nov. 2007, available at http://www.massbar.org/for-attorneys/publications/lawyersjournal/2007/november/civil-gideon-symposium-mobilizes-legal-community-behind-equal-justicein-law (last visited June 29, 2009).

For some non-symposium treatments of civil Gideon, see Paul Marvy \& Debra Gardner, A Civil Right To Counsel For the Poor, 32 Human Rights 8 (2005); John Nethercut, "This Issue Will Not Go Away....": Continuing to Seek the Right to Counsel in Civil Cases, 38 Clearinghouse Rev. 481 (2004); Deborah Perluss, Washington's Constitutional Right to Counsel in Civil Cases: Access to Justice v. Fundamental Interest, 2 SEATTLE J. FOR SOC. Just. 571 (2004); Rachel Klienman, Housing Gideon: The Right to Counsel in Eviction Cases, 31 FordHAm URB. L.J. 1507 (2004); Earl Johnson, Jr., Will Gideon's Trumpet Sound a New Melody? The Globalization of Constitutional Values and Its Implications for a Right to Equal Justice in Civil Cases, 2 SEATTLE J. For Soc. Just. 201 (2003); Earl Johnson, Jr., Equal Access to Justice: Comparing Access to Justice in the United States and Other Industrial Democracies, 24 FoRDHAM INT'L L.J. 83 (2000).

109 See American Bar Association, Report to the House of Delegates 7 (Aug. 7, 2006), available at http://www.abanet.org/legalservices/sclaid/downloads/06A112A.pdf (last visited July 5, 2009) (resolution unanimously approved by the ABA House of Delegates). "To shorthand it, we need a civil Gideon, that is, an expanded constitutional right to counsel in civil matters." Id. 
associations have declared support for the concept. ${ }^{110}$ There are a number of national and local groups advocating for civil Gideon in courts and legislatures. ${ }^{111}$

Civil Gideon's supporters have taken a number of different tacks. The most basic is to choose an area of civil law and argue that "fundamental fairness" requires appointed counsel. For example, Russell Engler has argued for civil Gideon in the context of domestic violence cases, ${ }^{112}$ Raymond Brescia does the same for eviction proceedings, ${ }^{113}$ Stephen Loffredo and Don Friedman push for a qualified right to counsel in welfare proceedings, 114 and Jaya Ramji-Nogales and her co-authors advocate a civil Gideon for asylum proceedings. ${ }^{115}$ The problem with each of these approaches is Lassiter and its presumption against the provision of counsel outside of imprisonment cases. Further, depending on how you measure the equities, none of these areas surpasses a government termination a citizen's right to parent her children.

\footnotetext{
110 Marie A. Fallinger, A Home of its Own: The Role of Poverty Law in Furthering Law Schools' Missions, 34 Fordham URB. L.J. 1173, 1173 n. 4 (2007) ("The Civil Gideon movement is a new national movement in over thirty states."); see also Scott Russell, Minnesota's Legal Safety Net: Many Hands Intertwined 66 BENCH \& B. MinN. 22 (2009); Thomas M. Burke, A Civil Gideon? Let the Debate Begin, 65 J. Mo. B. 5 (2009); Diane S. Diel, Speaking for the Justice System, 81 WIS. LaW. 5 (2008); Montana State Bar, State Bar Signs on to Letter to Obama, Mccain, 34 MonT. LaW. 11 (2008).

111 See, e.g., National Coalition for a Civil Right to Counsel, Home Page, at http://www.civilrighttocounsel.org/ (last visited December 31, 2009).

112 Russell Engler, Shaping a Context-Based Civil Gideon from the Dynamics of Social Change, 15 TEмP. PoL. \& Civ. RTS. L. REv. 697, 712 (2006).

113 Raymond H. Brescia, Sheltering Counsel: Towards a Right to a Lawyer in Eviction Proceedings, 25 Touro L. Rev. 187 (2009); see also Andrew Scherer, Why People Who Face Losing Their Homes in Legal Proceedings Must Have a Right to Counsel, 3 CARDozo PUB. L. PoL'Y \& ETHICS J. 699 (2006).

114 Stephen Loffredo \& Don Friedman, Gideon Meets Goldberg: The Case for a Qualified Right to Counsel in Welfare Hearings, 25 Touro L. Rev. 273 (2009).

115 Jaya Ramji-Nogales, et al., Refugee Roulette: Disparities in Asylum Adjudication, 60 STAN. L. Rev. 295, 384 (2007).
} 
An alternate strategy is to advocate for the reversal of Lassiter. ${ }^{116}$ Gideon itself offers some helpful parallels. For civil Gideon proponents Lassiter is just a reprise of Betts v. Brady. Just as Gideon wisely reversed Betts twenty-one years later, Lassiter is likewise ripe for reversal. ${ }^{117}$ Laura Abel, the co-Director of the Brennan Center, has added some other potential parallels. First, academics and some judges were openly scornful of both Betts and Lassiter. ${ }^{118}$ Second, like Lassiter, Betts called for a case-by-case determination of when the due process clause (and the Sixth Amendment) required the appointment of a lawyer. In Gideon this process was deemed unwieldy and unworkable, and Abel argues the same is true of Lassiter's case-by-case analysis. ${ }^{119}$ Lastly, Abel is hopeful that like the twenty-two states that filed a brief in support of Gideon, a coalition of states might be found to support the overturn of Lassiter. ${ }^{120}$

A further parallel is ABA and state bar support for civil Gideon. While the ABA was not closely involved with Gideon, its support for the extension of Gideon to misdemeanors was critical to the holding in Argesinger. Argesinger includes a lengthy quote from the ABA in support of appointing lawyers in misdemeanor cases. ${ }^{121}$ Argesinger also cites ABA authority for the proposition that there are sufficient existing lawyers and law students to meet the new constitutional

\footnotetext{
116 See Sweet, supra note _, at 506 ("The time has come to reverse Lassiter and provide counsel in civil litigation just as the Supreme Court in Gideon in 1963 reversed its holding in Betts v. Brady twenty-one years earlier and found for a right to counsel in all criminal proceedings."); Laura K. Abel, A Right to Counsel in Civil Cases: Lessons from Gideon v. Wainwright, 15 TEMP. PoL. \& Civ. RTS. L. Rev. 527, 530-35 (2006) (arguing that Lassiter, like Betts v. Brady before it, should be overturned).

117 Abel, supra note _, at 531.

118 Id. at 531-32.

119 Id. at 532-33.

120 Id. at 534-35.

121 Argesinger, 407 U.S. at 39.
} 
requirement ${ }^{122}$ and that some misdemeanors should be reclassified as non-crimes to lessen the need for appointed counsel. ${ }^{123}$ Chief Justice Burger's Argesinger concurrence noted that the ruling "should cause no surprise to the legal profession," because the ABA had advocated for it in 1968. Burger goes on to quote at length (and with approval) from two different ABA reports pushing for appointed lawyers in misdemeanor cases. ${ }^{124}$ Given the persuasive power of the ABA in Argesinger, the power of ABA support for civil Gideon is worth noting.

The fundamental problem, however, is that Lassiter was a case that arrived too long after the due process revolution of the 1960s and early 1970s. By 1981 the Court was in retrenchment mode. While membership on the court has turned over somewhat, it is quite unlikely that the current Court would even take a civil Gideon case, let alone reverse Lassiter. Similarly, this Court's sensitivity to ABA guidance or academic opprobrium (especially in comparison to the Gideon Court) is quite limited.

There have also been efforts to try to find a beachhead for civil Gideon in state constitutional law. Mary Helen McNeal has made the case under Montana constitutional law, for example. ${ }^{125}$ At one point it looked like Maryland might be the first state to recognize a broad civil Gideon right. In 2004 three Justices on the Maryland Supreme Court wrote a concurring opinion in Frase v. Barnhart that noted

\footnotetext{
122 Id. at 37 n.7.

123 Id. at 38 n. 9.

124 Id. at 43-44 (Burger, C.J., concurring).

125 Mary Helen McNeal, Toward a "Civil Gideon" Under the Montana Constitution: Parental Rights As the Starting Point, 66 MonT. L. REV. 81 (2005).
} 
the Maryland Constitution's due process and law of the land clauses, quoted heavily from the Lassiter dissents and asserted a civil Gideon right in that state. ${ }^{126}$

Nevertheless, two years later in Touzeau v. Deffinbaugh those same three Justices found themselves on the losing end of a 4-3 decision that closed the door on a civil Gideon right in Maryland. ${ }^{127}$ While there have been a smattering of state legislative successes, no state court has found any sort of broad civil Gideon right.128

The last group of civil Gideon advocates argue that treaty obligations and international law support a civil right to counsel. There is a growing international trend in favor of a right to civil counsel:

Indeed, the right to counsel in civil matters is well established as a general principle of law in the international community. The European Court of Human Rights has construed the European Convention for the Protection of Human Rights and Fundamental Freedoms to require a right to civil counsel. The Inter-American Court of Human Rights has also recognized the right. Nations from Ireland to Madagascar provide broad rights to counsel in civil matters, while others, such as South Africa, provide a right to counsel in certain matters involving fundamental rights, such as housing. Finally, the Human Rights Committee of the United Nations has addressed the right to counsel in civil matters, as have the Committee on the Elimination of All Forms of Racial Discrimination and other United Nations bodies. ${ }^{129}$

Moreover, the U.S. has signed several treaties - the International Covenant on Civil and Political Rights, the Charter of the Organization of American States and The

\footnotetext{
126 Frase v. Barnhart, 840 A.2d 114, 131-39 (Md. 2004) (Cathell, J. concurring).

127 Touzeau v. Deffinbaugh, 907 A.2d 807 (Md. 2006); see also Stephen J. Cullen \& Kelly A. Powers, The Last Huzzah for Civil Gideon, 41 MD. B.J. 24 (2008).

128 See Jason Boblick, A Consumer Protection Act?: Infringement of the Consumer Debtor's Due Process Rights Under the Bankruptcy Abuse Prevention and Consumer Protection Act of 2005, 40 ARIz. ST. L.J. 713, 735 \& n. 167 (2008).

129 Martha F. Davis, In the Interests of Justice: Human Rights and the Right to Counsel in Civil Cases, 25 TOURo L. REv. 147, 150-51 (2009).
} 
International Convention on the Elimination of All Forms of Racial Discrimination that require some form of civil representation for the poor..$^{130}$

These arguments seem somewhat compelling, although international law advocates have long advocated for treaties to remake American law and in most cases it proves to be rather less than hoped for. In particular, relying on treaties to overturn Supreme Court precedent or order large-scale new rights for poor people has not proven especially successful over the years. ${ }^{131}$

III. The Problems with Civil Gideon - The Problems with Gideon Itself Some advocates for civil Gideon have recognized that some aspects of the original Gideon would probably not be worth transporting to the civil arena. Civil Gideon proponent Laura Abel admits that " $[\mathrm{t}]$ here have been successes and failures in implementing Gideon."132 Many civil Gideon proponents, however, have attached themselves to the concept and language of Gideon without recognizing its significant shortcomings. This makes sense, because Gideon is an iconic, powerful and beautifully written case that expresses a vision of American justice that is attractive to all. Anthony Lewis' Gideon's Trumpet is perhaps the best non-fiction book about a legal case ever written..$^{133}$

\footnotetext{
130 See Sarah Paoletti, Deriving Support From International Law for the Right to Counsel in Civil Cases 15 TEMP. Pol. \& Civ. RTS. L. Rev. 651, 652-662 (2006).

131 See Joel R. Paul, The Rule of Law is Not for Everyone, 24 BERKELEY J. INT'L L. 1046, 1060 (2006)

(noting the example of segregation and arguing that "[d]espite the Constitution's Supremacy Clause, the United States has found treaty obligations to be inconvenient and often has refused to honor them").

132 Abel, supra note _, at 538-51.

133 AnTHONY LEWIS, GiDEon's TRumpet (1964). When I graduated from college my Aunt gave me Gideon's Trumpet in a naked attempt to convince me to go to law school. I read the book and enrolled a year later.
} 
Nevertheless, the reality of criminal defense for the indigent hardly matches the rhetoric. ${ }^{134}$ There is every reason to believe that if civil Gideon became a reality the situation on the civil side would be substantially worse.

As Stephen Bright, Director of the Southern Center for Human Rights, has said, "No constitutional right is celebrated so much in the abstract and observed so little in reality as the right to counsel."135 Gideon has foundered on two fronts. The first is the grossly inadequate funding of indigent criminal defense (leading to crippling per lawyer caseloads and assembly line justice). The second is a pathetically narrow definition of ineffective assistance of counsel. Taken together, every indigent defendant is guaranteed a warm body with a J.D., but we are far from Gideon's "noble ideal" of "impartial tribunals in which every defendant stands equal before the law."136

A. Funding, Caseload and the Inevitable Results

The funding for indigent defense has been described as a "crisis,"137 a "disgrace,"138 "underfunded,"139 "broken,"140 and “unconscionable."141 Deborah

\footnotetext{
134 This seems like an appropriate point to note that a significant portion of my teaching load includes working as appointed criminal defense counsel for indigent clients. In that work I have seen much, much fine lawyering, often from appointed private counsel or public defenders. The Knox County Public Defenders Office is, in my opinion, one of the best of its kind in the country and does admirable work within their resource constraints.

135 Stephen B. Bright, Gideon's Reality: After Four Decades, Where Are We?, CRIM. Just. 5 (Summer, 2003); see also DEBORAH L. RHODE, ACCESS TO JUSTICE 122-42 (2004).

136 Gideon, 372 U.S. at 344.

137 Nat'l Legal Aid \& Defender Ass'n, A Race to the Bottom, Speed and Savings over Due Process: A Constitutional Crisis (2008), http://www.mynlada.org/michigan/michigan_report.pdf (last visited July 5, 2009).

138 Barbara E. Bergman, Verbatim, ChAmpion, Sept.-Oct. 2005, at 41, 42.

139 Douglas W. Vick, Poorhouse Justice: Underfunded Indigent Defense Services and Arbitrary Death Sentences, 43 BufF. L. Rev. 329 (1995).

140 ABA Standing Comm. on Legal Aid \& Indigent Defendants, Gideon's Broken Promise: America's CONTINUING QUEST FOR EQUAL JUSTICE, REPORT OF THE AMERICAN BAR ASSOCIATION'S HEARING ON THE Right TO Counsel in CRiminal ProceEdings (2004).
} 
Rhode has done some exceptional work on documenting the funding differentials:

“The United States spends about a hundred billion dollars annually on criminal justice, but only about 2 to 3 percent goes to indigent defense. Over half is allocated to the police, and poor defendants receive only an eighth of the resources per case available to prosecutors." ${ }^{142}$

The news from the individual states is likewise grim. Mary Sue Backus and Paul Marcus have an exhaustive article that lists individual statistics and stories of funding problems in a diverse list of states: Georgia, Virginia, Louisiana, Pennsylvania, North Dakota, Kentucky, Ohio, Minnesota, Missouri, California, Mississippi, Arizona, and Massachusetts. ${ }^{143}$

In Knoxville, Tennessee, Mark Stephens, the County Public Defender, has repeatedly fought for higher funding, including refusing to take some appointments and attempting to withdraw from defending misdemeanors altogether. As support Stephens noted that one staff member alone had 60 cases set for trial, with another 37 new cases pending appointment in that same courtroom. ${ }^{144}$ A staff of 18 public defenders handles more than 10,000 misdemeanor charges each year and another 3,000 or more felony charges. ${ }^{145}$ Nevertheless, the local judges ordered Stephens to continue taking misdemeanors. ${ }^{146}$

\footnotetext{
${ }^{141}$ Anthony Paduano \& Clive A. Stafford Smith, The Unconscionability of Sub-Minimum Wages Paid Appointed Counsel in Capital Cases, 43 RuTGERS L. REv. 281 (1991).

142 RHODE, supra note _, at 123.

143 Mary Sue Backus \& Paul Marcus, The Right to Counsel in Criminal Cases, A National Crisis, 57 HASTINGS L.J. 1031, 1035-26 \& 1048-53 (2006).

144 Jamie Satterfield, Public Defender Battles Load, KnoxviLLE NewS Sent., July 19, 2007 at B1.

145 Jamie Satterfield, Overworked Attorneys Must Keep Caseloads, Knoxville News Sent., Feb. 26, 2009 at B1.

146 Id.
} 
Stephen Bright has also used the example of McDuffie County, Georgia. ${ }^{147}$ The county commission decided that it had been spending too much on indigent defense. The county commissioners decided to solicit bids. They specified no qualifications and their only goal was to cut costs. They awarded the contract to the lowest bidder at a $40 \%$ discount off of the old cost. For the first three years of the contract, the new lawyer tried only one felony case to a jury while entering 213 guilty pleas in felony cases and filing only three motions in the three years. ${ }^{148}$

The funding problems lead inevitably to crippling caseloads. Erica

Hashimoto offers multiple examples of excessive caseloads:

In 2003, public defenders statewide in Minnesota handled more than 900 cases per attorney per year. In 2001, a trial staff of fifty-two lawyers at the public defender office in Hamilton County, Ohio, which encompasses much of the Cincinnati metropolitan area, handled 34,644 cases, an average of 666 cases per attorney. In Maryland in 2002, the public defender office, which had not increased in size in five years, reported that it would have to hire 300 attorneys just to meet national caseload standards. In 1996, staff attorneys at the Office of the Public Defender in Orange County, California maintained caseloads of 610 cases. In 2004 in Kentucky, public defenders handled an average 489 cases per lawyer. ${ }^{149}$

These caseloads make it very unlikely that any individual client will receive a vigorous defense. As one public defender noted, it is not really very complicated math: "When caseloads are so high that a public defender can only spend 3.8 hours per case, including serious felony cases, [we] cannot ensure reliability." ${ }^{150}$ Studies of appointed counsel have found that the caseload and funding incentives have played out predictability. For instance, an infamous study of

\footnotetext{
147 Stephen B. Bright, Glimpses at a Dream Yet to be Realized, The ChAmpion 12, 14 (March 1998). 148 Id.

149 Erica Hashimoto, The Price of Misdemeanor Representation, 49 WM. \& MARY L. REv. 461, 471-72 (2007).

150 Backus \& Marcus, supra note _, at 1058.
} 
appointed counsel in New York City found that defense attorneys visited crime scenes and interviewed witnesses in only $21 \%$ of homicides and in a shocking $4 \%$ of non-homicide felonies. ${ }^{151}$ Defense counsel appointed experts in only $17 \%$ of the homicides and in just $2 \%$ of all felony cases. ${ }^{152}$ More recent studies suggest these figures are fairly typical. ${ }^{153}$

Likewise, systems that rely upon individual appointed defense counsel (as opposed to a permanent staff of public defenders) face significant structural problems. Any system that relies upon appointed counsel faces the danger that judges will appoint the lawyers that make their lives and the lives of prosecutors easiest: less competent or more compliant lawyers who will look to plead as many cases as possible. ${ }^{154}$ In systems where budget pressures are severe or there are caps on fees lawyers face natural pressures to do less (or as little as possible) on their cases, because any work beyond a fee cap is basically done for free. ${ }^{155}$ In systems where public defenders or appointed counsel carry a large caseload the interests of defense lawyers suddenly align powerfully with prosecutors and judges: their primary interest becomes the pursuit of efficient

151 See Michael McConville \& Chester L. Mirsky, Criminal Defense of the Poor in New York City, 15 N.Y.U. REV. L. \& Soc. CHANGE 581, 762-64 (1986-87).

152 Id.

153 See Darryl K. Brown, The Decline of Defense Counsel and the Rise of Accuracy in Criminal Adjudication, 93 CAL. L. REV. 1585, 1603 (2005); see also, Robert L. Spangenberg et al., $A$ Comprehensive Review of Indigent Defense in Virginia (Jan. 2004), http:// www.abanet.org/legalservices/downloads/sclaid/indigentdefense/va-report2004.pdf (study by the Spangenberg Group for the ABA); REPORT OF GEORGIA CHIEF JUSTICE'S COMMISSION ON INDIGENT DEFENSE (2003), available at http:// www.georgiacourts.org/aoc/press/idc/idchearings/idcreport.doc. 154 In a classic 1973 article Judge Bazelon stated a taxidermy of ineffective counsel, including "sweetheart lawyers" who depend on judges for continuing appointments and oblige by "moving cases along." David L. Bazelon, The Defective Assistance of Counsel, 42 U. Cin. L. REV. 1, 7-16 (1973). 155 William J. Stuntz, Christian Legal Theory, 116 HARV. L. REv. 1707, 1730-31 (2003) (reviewing Christian Perspectives On Legal Thought (Michael W. Mcconnell, Robert F. Cochran, Jr. \& Angela C. Carmella eds., 2001)). 
docket control. Game theory suggests that players in iterated games have greater incentives to cooperate than one-time players. ${ }^{156}$ In the game of criminal defense the judge, the criminal defense lawyers and the prosecutors are the regular players, the indigent defendants come and go.

Beyond the systematic evidence are a series of jaw-dropping anecdotes.

Consider just a few of those gathered by Backus and Marcus:

In a case of mistaken identity, Henry Earl Clark of Dallas was charged with a drug offense in Tyler, Texas. After his arrest, it took six weeks in jail before he was assigned a lawyer, as he was too poor to afford one on his own. It took seven more weeks after the appointment of the lawyer, until the case was dismissed, for it to become obvious that the police had arrested the wrong man.... During this time, he lost his job and his car, which was auctioned. After Clark was released, he spent several months in a homeless shelter.

Sixteen-year-old Denise Lockett was retarded and pregnant. Her baby died when she delivered it in a toilet in her home in a South Georgia housing project. Although an autopsy found no indication that the baby's death had been caused by any intentional act, the prosecutor charged Lockett with firstdegree murder. Her appointed lawyer had a contract to handle all the county's criminal cases, about 300 cases in a year, for a flat fee. He performed this work on top of that required by his private practice with paying clients. The lawyer conducted no investigation of the facts, introduced no evidence of his client's mental retardation or of the autopsy findings, and told her to plead guilty to manslaughter. She was sentenced to twenty years in prison.

A defendant in Missoula, Montana, was jailed for nearly six months leading up to his trial. During the months before his trial, the defendant met with his court-appointed attorney just two times. That attorney did nothing to investigate the defendant's allegations that police obtained evidence against him during an illegal search. A second court-appointed lawyer subsequently had the case dismissed. ${ }^{157}$

As William Stuntz has well stated "The result is that a typical indigent defendant receives not an advocate able and willing to make the best case for him, but an

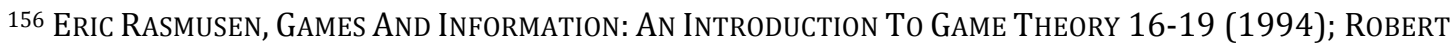
AXELROD, THE EVOLUTION OF COOPERATION 68-69 (1984).

157 Backus \& Marcus, supra note _, at 1031-33.
} 
overworked bureaucrat whose only realistic option is to plead the case out as quickly as possible."158 As a result dedicated former criminal defense lawyers suggest loosening the Sixth Amendment to recognize the necessity of indigent defense "triage"159 or that misdemeanor defense be abandoned altogether. ${ }^{160}$

Lawyers have challenged both the funding for indigent defense and caseloads, but courts have generally demurred and even in the cases where additional funding was awarded the gains proved short lived. ${ }^{161}$ Courts have avoided the issue through abstention doctrine, separation of powers concerns and a general distaste for overturning legislative budget decisions. ${ }^{162}$ An unwritten factor is undoubtedly how well an underfunded and overburdened system fits the judicial interest in rapidly processing huge dockets. More, better paid lawyers with fewer cases would likely change a system where $90 \%$ of convictions result from guilty pleas. ${ }^{163}$

\section{B. Ineffective Assistance of Counsel}

Despite all of these systemic problems, robust appellate review of ineffective assistance of counsel claims could at least offer some relief to defendants shuffled through the plea machine. Instead, Strickland v. Washington ${ }^{164}$ makes proving

\footnotetext{
158 Stuntz, supra note _, at 1730.

159 John B. Mitchell, In (Slightly Uncomfortable) Defense of "Triage" by Public Defenders, 39 VAL. U. L. Rev. 925 (2005); John B. Mitchell, Redefining the Sixth Amendment, 67 S. Cal. L. Rev. 1215 (1994). 160 Hashimoto, supra note _.

161 Note, Effectively Ineffective: The Failure of Courts to Address Underfunded Indigent Defense Systems, 118 HARV. L. REV. 1731, 1736 (2005).

162 Adam M. Gershowitz, Raise the Roof: A Default Rule for Indigent Defense, 40 CoNN. L. REv. 85, 89 (2007).

163 George C. Thomas III et al., Is It Ever Too Late for Innocence? Finality, Efficiency, and Claims of Innocence, 64 U. PITT. L. REv. 263, 295 (2003).

164 Strickland v. Washington, 466 U.S. 668 (1984).
} 
ineffective assistance of counsel quite difficult and guarantees that only the most serious and obvious cases of incompetence will result in relief.

Gideon was decided in 1963, but it was not until 1984 that the Court got around to defining ineffective assistance of counsel. The reticence to tackle this issue and the fact that Gideon guaranteed a lawyer, but gave no substance to the quality of that guarantee are part of a pattern with ineffective assistance: courts want to presume lawyers effective and move on. This is partially because some or many of the defendants claiming ineffective assistance are likely guilty, but the bigger part is every court's hesitance to call a fellow lawyer ineffective. For example, one of the earliest pre-Strickland standards for ineffective assistance was whether the lawyer was so bad he made the case a "farce and a mockery of justice."165

In Strickland the Court announced a two-prong test for ineffective assistance of counsel: a defendant must show that his lawyer's representation was deficient (the performance prong); and that the deficient performance affected the outcome (the prejudice prong). The performance prong requires “a showing that counsel's representation fell below an objective standard of reasonableness." ${ }^{166}$ The prejudice prong requires a showing that "there is a reasonable probability that, but for counsel's unprofessional errors, the result of the proceeding would have been different."167 The Court makes clear that if either prong fails, an ineffective

\footnotetext{
165 Diggs v. Welch, 148 F.2d 667, 669 (D.C. 1945). The case also includes a lengthy diatribe against habeus corpus actions and assumes that most prisoner complaints against their lawyers are an "exercise of ... imagination." Id. at 670.

166 Strickland, 466 U.S. at 687.

167 Id.
} 
assistance claim fails and that courts can consider either prong first. ${ }^{168}$ The combination of these two prongs and the Court's invitation to skip the performance prong to jump right to the prejudice prong, means that while the farce and mockery standard is technically dead its spirit lives on.

The Court's description of its standard for effectiveness leaves little doubt that it does not want to see attorney performance second-guessed or held ineffective with any great regularity. Consider the extremely loose "reasonably competent attorney" standard. ${ }^{169}$ The Court flatly refuses to classify any lawyer activity (other than a lawyer with an actual conflict of interest) as per se ineffective or unreasonable. ${ }^{170}$ Instead, the Court notes that lawyering is an "art," that lawyer behavior cannot be classified, that there are not "mechanical rules" in the area and, as a result, it cannot offer any specific guidance to lower courts about what particular behavior might be ineffective. ${ }^{171}$

Even after stating this extremely flexible standard the Court waters it down further by repeatedly emphasizing how deferential reviewing courts should be to lawyers. At points it appears the Court is struggling to find different ways of expressing their deference. Consider the following:

Judicial scrutiny of counsel's performance must be highly deferential. It is all too tempting for a defendant to second-guess counsel's assistance after conviction or adverse sentence, and it is all too easy for a court, examining counsel's defense after it has proved unsuccessful, to conclude that a particular act or omission of counsel was unreasonable.... Because of the difficulties inherent in making the evaluation, a court must indulge a strong presumption that counsel's conduct falls within the wide range of reasonable

\footnotetext{
168 Id. at 697.

169 Id. at 687.

170 Id. at 688-89.

171 Id.
} 
professional assistance; that is, the defendant must overcome the presumption that, under the circumstances, the challenged action might be considered sound trial strategy. There are countless ways to provide effective assistance in any given case. Even the best criminal defense attorneys would not defend a particular client in the same way. ${ }^{172}$

One might think the language above would be sufficient to protect against reviewing courts looking very carefully at these claims, but the Court keeps coming back to presumptions of effectiveness and deference. Immediately following the passage above, the Court reiterates "that counsel is strongly presumed to have rendered adequate assistance."173 One page later, the Court adds that reviewing courts should apply "a heavy measure of deference to counsel's judgments."174 Lastly, the Court reminds us of the "strong presumption of reliability."175

Nevertheless, the Court virtually guarantees that even the extremely deferential review it outlines above will rarely occur. This is because the Court requires a defendant to prove prejudice, "a reasonable probability that, but for counsel's unprofessional errors, the results of the proceeding would have been different. A reasonable probability is a probability sufficient to undermine confidence in the outcome."176 In practice, this has meant that a defendant must prove either innocence or the loss of an important substantive or procedural right. This is quite a stringent standard and many ineffective assistance claims fail on the prejudice prong.

172 Id. at 689.

173 Id. at 690.

174 Id. at 691.

175 Id. at 696.

176 Id. at 694. 
This works out nicely for courts that want to avoid labeling an attorney's

representation ineffective. The Court goes out of its way to make this point:

In particular, a court need not determine whether counsel's performance was deficient before examining the prejudice suffered by the defendant as a result of the alleged deficiencies. The object of an ineffectiveness claim is not to grade counsel's performance. If it is easier to dispose of an ineffectiveness claim on the ground of lack of sufficient prejudice, which we will expect will often be so, that course should be followed. ${ }^{177}$

Thus, even the prejudice prong is stacked to ensure that courts will not have to address the attorney behavior at issue.

There is also a procedural protection barring many ineffective assistance claims: those claims are generally brought in what's called "collateral proceedings," instead of on direct appeal. This means that the first time that most ineffective assistance claims are raised is in a federal habeus corpus or state collateral attack on a criminal conviction. ${ }^{178}$ These sorts of actions arise only after a criminal defendant has exhausted her direct appeals, which means that they occur years and years after the original trial. Thus, for anyone serving a sentence of fewer than 3-5 years, an ineffective assistance claim is unlikely. This practice insulates all of that defense work from review. 179

Not surprisingly, ineffective assistance claims are extremely hard to win and courts have proven deferential indeed. One example is the series of sleeping lawyer cases where the defendants have lost. As one judge famously opined, "The Constitution says that everyone is entitled to an attorney of their choice. But the

\footnotetext{
177 Id. at 697.

178 See Massaro v. U.S., 538 U.S. 500, 504-5 (2003).

179 See Eve Brensike Primus, Structural Reform in Criminal Defense: Relocating Ineffective Assistance of Counsel Claims, 92 CORNELL L. REv. 679 (2007).
} 
Constitution does not say that the lawyer has to be awake."180 Likewise, a Texas Appellate Court held that a sleeping lawyer's naps might have been a "strategic move" because "the jury might have sympathy for appellant because of" the naps. ${ }^{181}$ In analyzing these cases, some courts have used a three-part analysis: did counsel sleep often, was counsel unconscious or just resting, and did counsel miss a key part of the trial while asleep. ${ }^{182}$ Consider the following from Stephen Bright:

Calvin Burdine and Carl Johnson were represented at their capital trials in Houston by the same court-appointed attorney, who slept during parts of their trials. In Burdine's case, the clerk of the court testified that "defense counsel was asleep on several occasions on several days over the course of the proceedings." The lawyer's file on the case contained only three pages of notes. Nevertheless, the Texas Court of Criminal Appeals found that a sleeping attorney was sufficient "counsel" under the Sixth Amendment. Both the Texas Court of Criminal Appeals and the United States Court of Appeals for the Fifth Circuit held that Carl Johnson was not denied his Sixth Amendment right to counsel even though the lawyer slept through much of the trial and, as one observer noted, "the ineptitude of the lawyer ... jumps off the printed page." Neither court published its opinion. Carl Johnson was executed on September 19, 1995.183

Thus, ineffective assistance of counsel claims have hardly proven an effective protection against the individual woes of an underfunded, overburdened system of indigent defense.

C. The Corrosive Effects of the Betrayal of Gideon

180 Bruce Shapiro, Sleeping Lawyer Syndrome, ThE NATION, Apr. 7, 1997, at 27-29 (quoting Judge Doug Shaver).

181 McFarland v. State, 928 S.W. 2d 482, 506 n.20 (Tex. Crim. App. 1996).

182 See Burdine v. Johnson, 262 F.3d 336, 341 (5th Cir. 2001); Tippins v. Walker, 77 F.3d 682, 687-90

(2d Cir. 1996). Similarly, reviewing courts have deferentially reviewed allegations of lawyers who were drunk or high at the time of trial and denied some for a lack of prejudice. Ira Mickenberg, Drunk, Sleeping, and Incompetent Lawyers: Is It Possible to Keep Innocent People Off Death Row?, 29 U. DAYTon L. Rev. 319, 323 (2004) and Jeffrey L. Kirchmeier, Drink, Drugs, and Drowsiness: The Constitutional Right to Effective Assistance of Counsel and the Strickland Prejudice Requirement, 75 NEB. L. REv. 425, 426, 455-63 (1996) have good overviews of these cases. 183 Bright, supra note _, at 14. 
The combination of low funding, high case loads and little appellate oversight of lawyer quality has naturally resulted in a system that is plea driven and "depends less on adversarial process and more on practices akin to those found in administrative and inquisitorial settings."184 This perversion of the "noble ideal" of Gideon is more than merely ironic. It is positively corrosive to the rule of law.

Start from the point of view of the indigent defendants that make up approximately $80 \%$ of the criminal justice caseload. ${ }^{185}$ From the indigent client's perspective their lawyer is too often seen as part of the system, rather than as the shining knight envisioned by Gideon. Consider the following from Stephen Schulhofer and David Friedman:

Indigents commonly mistrust the public defender assigned to them and view him as part of the same court bureaucracy that is "processing" and convicting them. The lack of trust is a major obstacle to establishing an effective attorney-client relationship. The problem was captured in a sad exchange between a social science researcher and a prisoner: "Did you have a lawyer when you went to court?" "No. I had a public defender."186

This fundamental distrust does more than destroy the lawyer-client relationship: it makes a mockery of the promises made by Gideon and any arresting officer's offer of an appointed lawyer to an arrestee that cannot afford one.

Consider the effect on the entire criminal defense bar to have the bulk of clients "triaged" and knowing that almost any level of representation will be ruled effective on appeal. Both sides of the shame of Gideon have a powerful downward

184 Brown, supra note _, at 1587.

185 See Steven K. Smith \& Carol J. DeFrances, Indigent Defense, Bureau of Justice Statistics Selected FINDINGS 4 (1996) (noting data from the nation's 75 largest counties indicate that about $80 \%$ of felony defendants relied on either public defenders or assigned counsel for legal representation). 186 Stephen J. Schulhofer \& David D. Friedman, Rethinking Indigent Defense: Promoting Effective Representation Through Consumer Sovereignty and Freedom of Choice for All Criminal Defendants, 31 AM. CRIM. L. REV. 73, 86 (1993) (footnote omitted). 
pull on the quality of representation (as lowered standards and expectations are met) and on the quality of justice as a whole. As each player in the system gets used to cutting corners pretty soon a system designed as a square has become a circle.

Likewise, consider the psychological weight that incompetent lawyering imposes on all of the players in the system. Start with the judges and consider Judge David Bazelon’s classic phrase for some criminal defense lawyers, “[w]alking violations of the Sixth Amendment," as well as his description of the judicial struggle over how to handle these situations. ${ }^{187}$

Even the Supreme Court has expressed discomfort with the "assembly line justice" that America's criminal justice system now embodies. There is a long section in Argesinger v. Hamlin where the Court decries the state of the misdemeanor prosecution circa 1972:

[T] he volume of misdemeanor cases, far greater in number than felony prosecutions, may create an obsession for speedy dispositions, regardless of the fairness of the result. The Report by the President's Commission on Law Enforcement and Administration of Justice, The Challenge of Crime in a Free Society, states:

For example, until legislation last year increased the number of judges, the District of Columbia Court of General Sessions had four judges to process the preliminary stages of more than 1,500 felony cases, 7,500 serious misdemeanor cases, and 38,000 petty offenses and an equal number of traffic offenses per year. An inevitable consequence of volume that large is the almost total preoccupation in such a court with the movement of cases. The calendar is long, speed often is substituted for care, and casually arranged out-of-court compromise too often is substituted for adjudiciation. Inadequate attention tends to be given to the individual defendant, whether in protecting his rights, sifting the facts at trial, deciding the social risk he presents, or determining how to deal with him after conviction. The frequent result is futility and failure.

187 Bazelon, supra note _, at 2-15. 
Suddenly it becomes clear that for most defendants in the criminal process, there is scant regard for them as individuals. They are numbers on dockets, faceless ones to be processed and sent on their way. The gap between the theory and the reality is enormous. Very little such observation of the administration of criminal justice in operation is required to reach the conclusion that it suffers from basic ills.... The misdemeanor trial is characterized by insufficient and frequently irresponsible preparation on the part of the defense, the prosecution, and the court. Everything is rush, rush. There is evidence of the prejudice which results to misdemeanor defendants from this 'assembly-line justice.'188

There are a couple of poignant aspects to the above quote. It is sad to think of how little Argesinger itself did to ameliorate the problems listed above. If anything, things are worse now than before. ${ }^{189}$ Moreover, it is amazing that in 1972 (during the closing stages of the due process revolution), in an opinion written by Chief Justice Burger, the Court would write so eloquently about the death of the trial and the birth of the rushed, overcrowded assembly line of justice that has marked American justice from then until now.

Criminal defense lawyers also cannot help but notice the structural difficulties with the system or the regular appearance of substandard practitioners. ${ }^{190}$ Likewise prosecutors struggle with their role in a system that offers some defendants so little. ${ }^{191}$ In sum, no thoughtful participant or observer in the American justice system can fail to notice the grave gap between the rhetoric

\footnotetext{
188 Argesinger, 407 U.S. at 34-35.

189 Bureau of Justice Statistics, U.S. DeP't of Justice, Sourcebook for Criminal Justice Statistics 2003 at 405 tbl. 5.8 (noting criminal cases per federal judge rose from 63 in 1982 to 104 in 2003).

190 See Penny J. White, Mourning and Celebrating Gideon's Fortieth, 72 UMKC L. REV. 515, 515-518 (2003).

191 Compare Fred C. Zacharias, Structuring the Ethics of Prosecutorial Trial Practice: Can Prosecutors Do Justice?, 44 VAND. L. REV. 45 (1991) (arguing for aggressive and regular prosecutorial reporting of substandard defense work) with Vanessa Merton, What Do You Do When You Meet a "Walking Violation of the Sixth Amendment" If You're Trying to Put That Lawyer's Client in Jail?, 69 FoRDHAM L. REV. 997 (2000) (arguing that such a system would prove unworkable in practice).
} 
and the reality. Hypocrisy of this kind does more than disappoint: it devours a system from the inside out and mocks the meat it feeds on. ${ }^{192}$

\section{Do We Really Want to Transplant Gideon's Baggage to Civil Settings?}

Let me start by saying that if the criminal justice system is a travesty, the great bulk of the current pro se civil justice system is even worse. Nevertheless, unlike civil Gideon there are signs that efforts to ameliorate pro se civil representation are occurring and accelerating. More importantly, real court reform would prove much, much more egalitarian or workable than a civil Gideon system.

In fact, the corrosive effects of Gideon would likely be greatly amplified in the civil setting. First, note that the problems of crippling caseloads and woeful funding occur in the context of serious crimes. In fact, many of the most powerful examples of Gideon's failures come in death penalty cases. ${ }^{193}$ If reviewing courts and legislatures cannot see the worth in adequately funding capital defense, what hope is there for adequate funding for defense of a termination of parental rights proceeding, let alone a landlord-tenant action?

Similarly, consider the annual battles over legal aid funding as a precursor. Advocates for the poor have long complained about legal aid's woeful funding. ${ }^{194}$

192 See WiLliam SHAKESPEARE, OTHELlo act 3, sc. 3.

193 See Stephen Bright, Address at the Maryland School of Law, Gideon - A Generation Later: Introduction \& Keynote Speakers, 58 MD. L. REV. 1333 (1999). 194 Van O'Steen, Bates v. State Bar of Arizona: The Personal Account of a Party and the Consumer Benefits of Lawyer Advertising, 37 ARIZ. ST. L.J. 245, 246 (2005). Deborah M. Weissman, Law as Largess: Shifting Paradigms of Law for the Poor, 44 WM. \& MARY L. REV. 737, 756 (2002). 
Given the choke back in legal aid funding and the addition of restrictions on that funding, ${ }^{195}$ the hopes for warm legislative support of civil Gideon are unfounded.

There is also the possibility that creating a civil Gideon would export the debilitating disrespect for the rule of law that has followed along with Gideon. It is not hard to imagine the same pro se courts that are choked with litigants today staffed by one or two government paid lawyers (at the lowest salary possible) taking on 60 eviction cases a day, with the same results as Gideon's criminal defense: little individual attention, investigation or advocacy. In short, civil Gideon would likely look like criminal Gideon on steroids - overwhelmed lawyers, frustrated clients and no justice.

Civil Gideon would also likely spark a civil Strickland - as a constitutional guarantee of counsel would necessarily implicate some minimum standard for lawyer competence. This standard would likely be the same or even lower than Strickland, with the inevitable effect that extremely poor lawyering in civil courts would be acceptable as "effective." Gideon's shortcomings would only be exacerbated in a civil transplant.

E. The Jurisprudential Difficulties with Civil Gideon Along with the many logistical concerns listed above, there are significant jurisprudential reasons for avoiding an expansion of Gideon to civil cases. Gideon is part of a pantheon of cases that are considered unassailable and obviously correct ${ }^{196}$

195 See Rebekah Diller \& Emily Savner, Brennan Center for Justice: A Call to End Restrictions on Legal Aid for the Poor, http://brennan.3cdn.net/7e05061cc505311545 75m6ivw3x.pdf (last visited October 15, 2009).

196 See. e.g., James E. Moliterno, The Lawyer as Catalyst of Social Change, 77 FoRD. L. REv. 1559, 1559

(2009) (listing Brown and Gideon among the "great social change cases"). 
and this Article does not dispute the correctness of Gideon in principle.

Nevertheless, because Gideon itself was not a foreseen application of either the Sixth Amendment or the Due Process Clause it should be expanded carefully. While it may be true that Gideon was based upon the "obvious truth" that indigent felony defendants need representation for a fair trial, it is not necessarily true that all further applications are. The trick is to tease out which are and which are not.

Gideon is a classic living constitution case. This is because neither the framers of the Sixth Amendment or the Fourteenth Amendment expected that these amendments would guarantee a free lawyer to indigent defendants. A defendant's right to have a lawyer if he could afford one was well established at the time of the passage of the Bill of Rights in both federal and state trials and it is that right that the original Sixth Amendment protects. ${ }^{197}$ This is so because there certainly was not a right to appointed counsel at the time of the passage of the Bill of Rights. ${ }^{198}$ If the Framers had known that the Sixth Amendment might guarantee a government supplied lawyer to criminal defendants, ratification debates would have likely mentioned it and the right to counsel would have been much more controversial.

Instead, the right to counsel was the subject of little debate ${ }^{199}$ and gave federal constitutional standing to a rule that was already in effect in the colonies and at American common law. The Sixth Amendment right to assistance of counsel was a clear rejection of English common law, which allowed defense lawyers in

\footnotetext{
197 Note that the original Virginia Constitution did not contain a right to counsel guarantee. Nor does the current version.

198 See James T. Tomkovicz, The Right to Assistance of Counsel 20-21 (2002); William M. Beavy, The Right TO COUNSEL IN AMERICAN COURTS 24 (1955).

199 AKhil Reed Amar, The Bill of Rights: Creation and Reconstruction 278-79 (1998).
} 
misdemeanor prosecutions, but not in the more serious cases of treason or a felony. ${ }^{200}$ Since most felonies at common law were punishable by death, this meant that British defendants were allowed counsel in less serious cases but not in potential death penalty cases. ${ }^{201}$

Although this rule was adhered to in England until 1836, it was rejected by the American colonies. Twelve of the thirteen colonies lawfully recognized the right of appearance of counsel in all criminal prosecutions, with the exception of one or two instances in which it was limited to more serious crimes. ${ }^{202}$ Thus, there was little controversy or discussion over the right to counsel. When the framers drafted the Sixth Amendment, the inclusion of the right to counsel formalized a right that was already well established in the States.

Nevertheless, there was not universal or even regular appointment of counsel in felony cases at that time, and the appointments that occurred were as a result of a statute and not any constitutional mandate. Betts v. Brady may have been dead wrong as a matter of policy, justice or fairness, but it was spot on with its history. Betts carefully canvassed state constitutional and statutory law at the time of the passage of the Sixth Amendment and concluded that the state constitutions only protected the right to be represented by counsel, not a right to free appointed

\footnotetext{
200 David J. Bodenhamer, FAir TRial 39-40 (1992).

201 This was justified because judges were seen as neutral and able to protect the rights of the accused and also as an expedience in prosecuting particularly serious crimes. See BoDENHAMER, supra note _ , at 39-40.

202 Powell v. Alabama, 287 U.S. 45, 60-66 (1932) offers an excellent overview of the various colonial treatments of the right to counsel.
} 
counsel. ${ }^{203}$ Moreover, if a free lawyer was provided it was generally by statute and limited to death penalty cases. ${ }^{204}$

Likewise, at the time of the passage of the Fourteenth Amendment there was not a well-established right to appointed counsel. The mid-nineteenth century was, in fact, a time of court de-professionalization where in many states there were virtually no requirements for admission to the bar and pro se practice was quite common. ${ }^{205}$

So, based on any original understanding of the Sixth or Fourteenth Amendments Gideon is clearly a living constitution case. In fact, Gideon itself

203 Betts, 316 U.S. at 465-66.

204 Here is the passage from Betts that lays all this out. Connecticut was the outlier in apparently granting counsel in all criminal trials:

Connecticut had no statute although it was the custom of the courts to assign counsel in all criminal cases. Swift, 'System of Laws, Connecticut', 1796, Vol. II, p. 392. In Delaware Penn's Laws of 1719, ch. XXII and in Pennsylvania the Act of May 31, 1718, s III (Mitchell and Flanders' Statutes at Large of Penna., 1682-1801, Vol. III, p. 201) provided for appointment only in case of 'felonies of death'. Georgia has never had any law on the subject. Maryland had no such law at the time of the adoption of the Bill of Rights. An Act of 1777 in Massachusetts gave the right to have counsel appointed in cases of treason or misprision of treason. Laws of the Commonwealth of Massachusetts from Nov. 28, 1780 to Feb. 28, 1807, Ch. LXXI, Vol. II, Appendix, p. 1049. By an Act of Feb. 8, 1791, New Hampshire required appointment in all cases where the punishment was death. Metcalf's Laws of New Hampshire, 1916, Vol. 5, pp. 596, 599. An Act of New Jersey of Mch. 6, 1795, s 2, required appointment in the case of any person tried upon an indictment. Acts of the General Assembly of the Session of 1794, Ch. DXXXII, p. 1012. New York apparently had no statute on the subject. See Act Feb. 20, 1787, Laws of New York, Sessions 1st to 20th (1798), Vol. I, pp. 356-7. An Act of 1777 of North Carolina made no provision for appointment, but accorded defendants the right to have counsel. Laws of North Carolina, 1789, pp. 40, 56. Rhode Island had no statute until 1798 when one was passed in the words of the Sixth Amendment. Laws 1798, p. 80. South Carolina. by Act of August 20, 1731, limited appointment to capital cases. Grimke's So. Car. Pub. Laws, 1682-1790, p. 130. Virginia, by Act of Oct. 1786, enacted with respect to one charged with treason or felony that 'the court shall allow him counsel $* * *$ if he desire it.' Hening's Statutes of Virginia, 1785-1788, Vol. 12, p. 343.

Id. at 467 n. 20.

205 See Benjamin H. Barton, An Institutional Analysis of Lawyer Regulation: Who Should Control Lawyer Regulation - Courts, Legislatures, or The Market?, 37 GA. L. REV. 1167, 1243 \& n. 284 (2003). 
inspired an early use of that phrase in an article by Charles A. Reich entitled $M r$. Justice Black and the Living Constitution. ${ }^{206}$

Nevertheless, the Court has made clear that the Due Process Clause is "a concept less rigid and more fluid than those envisaged in other specific and particular provisions of the Bill of Rights" and is to be tested against notions of "fundamental fairness" and not a rigid application of the framers' intent. ${ }^{207}$ So, Gideon was certainly on firm ground in reading the Due Process Clause according to contemporary standards of fundamental fairness. ${ }^{208}$ Gideon's appeal to the "obvious truth" that a felony defendant could not navigate a trial without appointed counsel also fit the Court's flexible approach to due process.

Nevertheless, the key problem with expanding Gideon is that every step beyond the "obvious truth" of felony defense and the general consensus among the states that Betts should be overruled weakens the force of Gideon. If we start from the premise that Gideon was unquestionably correct, we still have to craft criteria for expansion. Without such criteria the Court risks replacing legislatively crafted funding priorities with judicial priorities. When there is a demonstrable shift in pubic opinion and an obvious miscarriage of justice as in Gideon the Court is on firm ground.

206 Charles A. Reich, Mr. Justice Black and the Living Constitution, 76 HARv. L. Rev. 673, 714 (1963).

207 This language comes from Betts itself, $i d$. at 462.

208 Nevertheless, in this regard Betts was also relatively persuasive. The case includes an exhaustive canvas of the contemporary state statutory and constitutional treatment of the appointment of counsel and concluded that "in the great majority of the states, it has been the considered judgment of the people, their representatives and their courts that appointment of counsel is not a fundamental right, essential to a fair trial. On the contrary, the matter has generally been deemed one of legislative policy." Id. at 467-71. One notable difference between Betts and Gideon is a shift in the states. The last paragraph of Gideon powerfully demonstrates this fact: "Florida, supported by two other States, has asked that Betts v. Brady be left intact. Twenty-two States, as friends of the Court, argue that Betts was 'an anachronism when handed down' and that it should now be overruled. We agree.” Gideon, 372 U.S. at 345. 
As the Court strays from firm ground messy problems arise. The guarantee of appointed misdemeanor counsel in Argesinger is an excellent example. The Court rejected the opportunity to limit the right to appointed counsel to more serious cases in the same manner that it had limited the right to a jury trial - to non-petty offenses. ${ }^{209}$ Instead the Court held that before an indigent defendant can be convicted and spend a single day in jail she must have had the service of an appointed lawyer.

Argesinger is problematic in a number of regards. First, unlike Gideon, appointed misdemeanor counsel was not common in the federal or state court systems and there was not a groundswell of support from the states or elsewhere for such a holding. ${ }^{210}$ In Gideon the federal courts had long guaranteed counsel for felonies and many states did as well. Argesinger is silent on this point, but the briefs suggest that neither the federal court practice nor federal statutes extended the right to appointed counsel as far as Argesinger did and that only a handful of states assigned attorneys in similar circumstances. ${ }^{211}$

Second, Argesinger privileged the right to appointed counsel - which was not an original right in the Sixth Amendment - above the right to a jury, which historically was considered to be the single most important Sixth Amendment right. ${ }^{212}$ Thomas Jefferson, among other framers, considered the right to a jury of

\footnotetext{
209 Argesinger, 407 U.S. at 28-31. Duncan v. Louisiana, 391 U.S. 145 (1968) limited the jury trial to non-petty offenses.

210 Unlike Gideon, there was only one amicus brief from a State in Argesinger: the State of Utah argued for the petty/non-petty distinction. See Brief for the State of Utah, Argesinger v. Hamlin, 407 U.S. 25 (1972) (No. 70-5015), 1971 WL 126422.

211 See Brief of the United States as Amicus Curiae, Argesinger v. Hamlin, 407 U.S. 25 (1972) (No. 70 5015), 1971 WL 126425, at*29-30.

212 Benjamin H. Barton, The Lawyer-Judge Bias, Ch. 3 (2009) (manuscript on file with author).
} 
paramount importance: "Were I called upon to decide whether the people had best be omitted in the Legislative or Judiciary department, I would say it is better to leave them out of the Legislative. The execution of the laws is more important than the making of them." ${ }^{213}$ This created an anomalous result within the due process revolution of the 1960s: the procedural right most valued by the framers (the jury trial) was treated worse than a right not even recognized at the time of the framing (a right to appointed counsel in virtually all criminal trials). ${ }^{214}$

Third, assigning counsel when even one day may be spent in jail sets a relatively low barrier for the liberty interest involved and creates future line drawing problems. The best argument against Lassiter is that many parents would spend much more than a day in jail to avoid losing their parental rights. If the Constitution requires an appointed lawyer in one case, it seems perverse to deny it in the other.

Lastly, and most importantly, there is an excellent argument to be made that the inglorious fate of Gideon was sealed with Argesinger. It was not impossible to predict that misdemeanor representation might overwhelm the system for appointing lawyers or that the inevitably high caseloads might result in substandard

\footnotetext{
213 Letter from Thomas Jefferson to Abbe Arnoux (July 19, 1789), in 5 The Founders' Constitution 364 (Philip B. Kurland \& Ralph Lerner eds., 1987). Similarly, John Adams wrote that juries should have "as compleat a Controul, as decisive a Negative, in every Judgment of a Court of Judicature" as the legislature has to veto executive action. John Adams, Diary Notes on the Right of Juries (Feb. 12, 1771), in 1 LEgAL PAPERS OF JOHN ADAMS 229 (L. Kinvin Wroth \& Hiller B. Zobel eds., 1965).

${ }^{214}$ In fact, the petty crime exception to the right to a jury trial is one of the very few areas of the 1960 s due process revolution where individual rights went backwards. Both in federal and state law, the petty crime exception was not firmly established at six months of potential imprisonment before Duncan v. Louisiana, 391 U.S. 145, 148-56 (1968). Afterwards the exception became much more regularized and national. Amar, supra note _, at 289-90.
} 
lawyering. To the contrary, both the Argesinger majority and the concurrence that rejected a mandate for appointed counsel discussed that exact issue. ${ }^{215}$

The above arguments against Argesinger are even more potent for civil Gideon. In Lassiter no state had found a broad based constitutional right to civil representation for the indigent. While most states did so in termination of parental rights cases as a matter of statute, none of those states pushed in favor of such a constitutional right in Lassiter, while six states joined a brief arguing the opposite. ${ }^{216}$ Civil Gideon proponents have wisely begun to lobby states to support a right to appointed civil counsel, ${ }^{217}$ but under the current fiscal circumstances that effort appears rather quixotic.

There are also reasons to be concerned about the role of judges choosing when the state should pay for appointed lawyers. I have argued elsewhere that there is a powerful lawyer-judge bias, i.e. judges will frequently privilege the legal profession in their decisions, constitutional or otherwise. ${ }^{218}$ For civil Gideon the interests of judges and lawyers do not necessarily square with the indigent, let alone the public at large. In civil Gideon (as elsewhere) lawyers have an incentive to prefer more employment to less. Thus we see the ABA and a number of state bars pushing for a right to appointed civil counsel. ${ }^{219}$ Likewise, judges are generally

\footnotetext{
215 Argesinger, 407 U.S. at 37 \& n. 7; Id. at 58-62 (Powell, J., concurring).

216 See Brief for the State of North Carolina, Amicus Curiae, Joined by the Attorneys General of Delaware and Mississippi, and the States of Florida, Nevada and Arkansas, Amici Curiae, Lassiter v. DSS, 452 U.S. 18 (1981) (No. 79-6423), 1980 WL 340039.

217 See Meredith Hobbs, Litigators Push for Civil Gideon, http://www.law.com/jsp/ca/PubArticleCA.jsp?id=1202426606743\&slreturn=1\&hbxlogin=1 (last visited October 15, 2009) (noting that civil Gideon advocates are lobbying state and local governments as well as pursuing litigation strategies).

218 See BARTON, supra note _..

219 See infra notes __ and accompanying text.
} 
hostile to pro se litigation and the more represented parties there are the easier most judge's jobs will be. ${ }^{220}$

Exactly how the preferences of indigent litigants are considered, however, is harder to see. Obviously all else being equal any litigant would prefer a fairer court procedure. When the cost of a civil Gideon is factored in, however, it becomes a harder question. For example, it would not be irrational for poor litigants to prefer that any money spent on their problems go to direct assistance, rather than a free lawyer. For example, if an indigent person facing eviction had a choice, she would often choose help with finding a new apartment or a few more weeks in their apartment over a free, but overburdened and underpaid, lawyer. Moreover, if it is true that pro se court reform can make the system fairer at a lower cost, indigent litigants might prefer that option.

In this regard the civil Gideon movement is reminiscent of the Court's differential treatment between procedural due process rights and substantive due process rights. When faced with an aggrieved poor person the Court has either offered extra levels of process or turned its back. ${ }^{221}$ Nevertheless, process can never replace substance. So, before a welfare recipient can lose her benefits the Court has held that the government must provide a hearing and other levels of due process. ${ }^{222}$ Nevertheless, there is no absolute right to welfare benefits or any other government

220 See Jonathan D. Glater, In a Downturn More Act as Their Own Lawyers, N.Y. Times, Apr. 9, 2009, at A1 (describing judicial difficulties with a surge in pro se litigation).

221 Compare Goldberg v. Kelly, 397 U.S. 254, 264 (1970) (holding that procedural due process requires a hearing before the termination of a welfare recipient's benefits) with Dandridge v. Williams, 397 U.S. 471, 484, 486 (1970) (no right to welfare benefits); Lindsey v. Normet, 405 U.S. 56 (1972) (no right to basic shelter either).

222 See Goldberg, 397 U.S. at 264. 
assistance. ${ }^{223}$ It says a lot about the mindset of judges that the high water mark for constitutional rights for the poor is the right to a hearing, rather than a right to basic sustenance or shelter. That said, from an indigent person's point of view, which would you rather have: a hearing or a right to the benefit itself?

In sum, it is fair to be suspicious of courts and bar associations when they come to help the poor. Experience teaches that the most the poor can hope for is more lawyers or more process, with little of substance to show for it. Moreover, it is not clear that spending on poverty programs is not a zero sum game. If that is the case, the choice of process over substance was doubly destructive: paying for the layers of due process that now "protect" the poor from losing various benefits may actually lower the absolute amount of those benefits. If the same were true of paying for a civil Gideon the appointment of free civil lawyers would be particularly ironic.

IV. Pro se Reform

Even if the above argument is wrong on the merits and as a matter of policy, why is it that the answer to this sort of challenge is always more lawyers? Why not a change in the nature of the courts? Keep in mind that the question of a remedy is different from the question of a constitutional violation. Even if the civil Gideon proponents are spot on that forcing indigent civil litigants to proceed pro se is a violation of fundamental fairness and due process, they are not necessarily correct that a free lawyer is the appropriate response. A court could just as easily order fundamental changes in court procedures as a remedy. Below I lay out the

223 Dandridge, 397 U.S. at 484, 486 (1970) (no right to welfare benefits); Lindsey, 405 U.S. at 56 (1972) (no right to basic shelter); see also Goldberg, 397 U.S. at 262. 
argument for the superiority of pro se court reform as a solution to an undeniable problem.

First a word of definition is necessary. When this Article refers to pro se court reform, that phrase means the reform of courts that feature a regularized majority (or at least plurality) of pro se matters. These courts are targeted because they are the most likely to be open to reform out of necessity. Further, if all of these courts were reformed it would make a massive difference in the lives of people too poor to hire their own lawyers.

\section{A. It Is Already Starting to Happen}

Aside from the arguments listed above against civil Gideon, there remains a very prosaic reason to prefer pro se court reform to civil Gideon: pro se reform may actually happen. Civil Gideon has gained traction with bar associations, legal academics and many advocates for the poor. Nevertheless, it has gained little traction among the constituencies that matter - the judges and justices who might require it constitutionally and the state and federal legislatures who could pass legislation granting it.224 Under the current fiscal situations of the state and federal governments legislative action appears remote indeed. Similarly, courts that were already reticent to order the appointment of free lawyers in civil cases will be even more hesitant.

By comparison, the pro se court reform train is warmed up and leaving the station. This is largely by necessity. Whether courts want to avoid it or not, waves

224 See supra notes __ and accompanying text. 
of pro se litigants are now the norm in many lower courts across the country and court reform - while difficult - is often the only solution.

The first and best sign of progress are publications, conferences and discussions among state court judges. ${ }^{225}$ In 2005, the American Judicature Society published a guide entitled Reaching Out or Overreaching: Judicial Ethics and SelfRepresented Litigants. ${ }^{226}$ It includes a long list of common sense things that judges are allowed to do to help pro se litigants, including making procedural accommodations, being courteous, avoiding legal jargon and procedural snafus, explaining the process, avoiding over-familiarity with lawyers in the courtroom, and training court staff so they provide patient, helpful service to self-represented litigants.227 It also includes a long section on "Best Practices for Cases Involving Self-Represented Litigants."228 This report follows up on 1998's Meeting the Challenge of Pro Se Litigation. ${ }^{229}$ AJS has also published a set of core materials that gathers the best and most innovative approaches to pro se reform being used nationally. ${ }^{230}$

\footnotetext{
225 Note that the analogous civil Gideon conferences and discussions are held by litigators and academics not judges. See, e.g., Brennan Center for Justice, Civil Gideon Symposium to Open ABA's Equal Justice Conference; Request for Papers on Right to Civil Counsel for Temple Political and Civil Rights Law Review, http://www.brennancenter.org/content/elert/civil_gideon_symposium_to_open_aba_s_equal_justice _conference_request_for_p/.

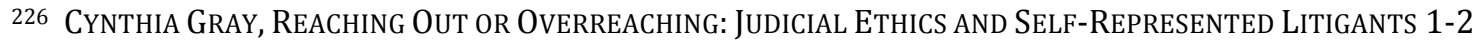
(2005).

227 GRAY, supra note _, at 1-2. This list of activities is so basic as to be humorous to a poverty lawyer, but sadly many or most courts addressing pro se litigants fail to follow these simple steps. The guide reminds me of the Simpsons episode where Homer has to take a court-mandated parenting class and the instructor tells the class to "put your garbage in a garbage can, people. I can't stress that enough. Don't just throw it out the window." Homer responds "Garbage in garbage can ... hmm, makes sense." The Simpsons: Home Sweet Homediddly-Dum-Doodily (Fox television broadcast Oct. 1, 1995). 228 GRAY, supra note _, at 51-58.

229 Jona Goldschmidt, et Al., MeEting the Challenge of Pro Se Litigation (1998).

230 The Self Represented Litigation Network, Core Materals on Self-Represented Litigation INNOVATION (2006).
} 
In 2002 the National Center for State Courts released The Self-Help Friendly Court: Designed from the Ground Up to Work for People Without Lawyers. ${ }^{231}$ The Preface is written by the Chief Justice of the California Supreme Court and references California's recent efforts, including a 900-page self help web site visited by over 100,000 people a month. ${ }^{232}$ While these guides are not perfect or particularly visionary, if pro se courts around the country adopted their suggested reforms it would make a huge difference in the lives of the indigent, as well as making the courts fairer and more efficient.

The California website is just one of many governmental or non-profit sites that aim to ease the pro se experience. SelfHelpSupport.org is a website set up for courts, community groups, poverty lawyers and academics interested in forwarding the cause of pro se reform. ${ }^{233}$ Lawhelp.org is a Probono.net website that is aimed at pro se litigants themselves and forwards the litigants on to each state's legal aid website, some of which are stronger than others. Nevertheless, it is a free site aimed at helping pro se litigants.

There are a number of individual courts that are trying quite innovative approaches. For example, Lois Bloom and Helen Herschkoff describe the creation of a special federal magistrate position in the Eastern District of New York assigned to hear significant categories of pro se matters, the first federal district to assign a

\footnotetext{
231 Richard ZorZa, The SElF-Help Friendly Court: Designed From the Ground UP to Work For People WITHOUT LAWYERS (2002), available at http://www.ncsconline.org/WC/Publications/Res_ProSe_SelfHelpCtPub.pdf. AJS actually has a whole website dedicated to the topic, www.ajs.org/prose/home.asp.

232 Zorza, supra note _, at 7-8. The web site can be found here: http://www.courtinfo.ca.gov/selfhelp/ (last visited July 7, 2009). ${ }^{233}$ See www.selfhelpsupport.org (last visited July 7, 2009).
} 
single magistrate in this manner. ${ }^{234}$ Ronald Staudt and Paula Hannaford have gathered a number of innovative court processes into one National Center for State Courts supported research project. ${ }^{235}$ San Antonio and other cities have established specialized pro se courts adopting many of the suggestions for court structure listed above. ${ }^{236}$

There has been significant scholarly interest in the topic as well. Russell Engler has written two tremendous articles on pro se reform. The first advocates a mass shift in the roles of clerks, judges and mediators to meet the new prominence of pro se and the second explores the judicial ethical challenges (and opportunities) involved in such a shift. ${ }^{237}$ Russell Pearce has argued that judges in pro se courts should replace the traditional role of neutral arbiter with active questioning aimed at ensuring that procedural and substantive justice prevails. ${ }^{238}$ Naturally, there have been critics and opponents, ${ }^{239}$ but the discussion itself, as well as the very real progress being made in multiple jurisdictions, is heartening.

\footnotetext{
234 See Lois Bloom \& Helen Hershkoff, Federal Courts, Magistrate Judges, and the Pro Se Plaintiff, 16 Notre Dame J.L. EThics \& Pub. PoL'Y 475, 476-77 (2002).

235 See Ronald W. Staudt \& Paula L. Hannaford, Access to Justice for the Self-Represented Litigant: An Interdisciplinary Investigation by Designers and Lawyers, 52 SYRACUSE L. REV. 1017 (2002).

236 See Anita Davis, A Pro Se Program That is Also "Pro" Judges, Lawyers, and the Public, 63 TEx. B.J. $896(2000)$.

237 See Russell Engler, And Justice for All - Including the Unrepresented Poor: Revisiting the Roles of Judges, Mediators, and Clerks, 67 FoRDHAM L. REv. 1987 (1999); Russell Engler, Ethics in Transition: Unrepresented Litigants and the Changing Judicial Role, 22 Notre Dame J.L. Ethics \& PuB. PoL'Y 367 (2008). Two other terrific articles discussing changes necessary to make pro se litigation work are Jona Goldschmidt, The Pro Se Litigant's Struggle for Access to Justice, 40 FAM. CT. REv. 36 (2002); Paris R. Baldacci, Assuring Access to Justice: The Role of the Judge in Assisting Pro Se Litigants in Litigating Their Cases in New York City's Housing Court, 3 Cardozo Pub. L. PoL'Y \& ETHICS J. 659 (2006).

238 Russell G. Pearce, Redressing Inequality in the Market for Justice: Why Access To Lawyers Will Never Solve the Problem and Why Rethinking the Role of Judges Will Help, 73 FoRDHAM L. REv. 969 (2004). 239 See, e.g., Drew A. Swank, In Defense of Rules and Roles: The Need to Curb Extreme Forms of Pro Se Assistance and Accommodation in Litigation, 54 AM. U. L. REV. 1537 (2005) (arguing that pro se assistance has gone too far); Frank V. Williams III, Reinventing the Courts: The Frontiers of Judicial Activism in the State Courts, 29 CAMPBELL L. Rev. 591 (2007) (arguing that pro se accommodation is part of a larger trend of judicial over-reaching and activism).
} 


\section{B. The Tip of the Spear}

The thing that is most promising about the proposals and programs outlined above is how very, very modest they are. Many pro se assistance projects actually involve very little change in the courts or clerks offices themselves. Instead they involve better preparing pro se litigants to appear by themselves in a traditional courtroom. ${ }^{240}$ Even the projects above involve very, very incremental change: creating a special court for pro se litigants, allowing clerks to give limited advice or treating pro se litigants respectfully. As such, a great deal of reform can be accomplished for relatively little expense: retraining all court personnel (and especially judges and clerks) to make special efforts to improve the experience of pro se litigants alone would make a very big difference.

The next level of reform is likewise relatively inexpensive, but it requires more thought and effort. Court processes and forms should all be revamped to assist pro se litigants. This requires the creation of form pleadings and greater transparency and clarity in court processes, so that pro se litigants can easily navigate the paperwork and court experience.

There is even a further type of reform possible, and here is where the real promise of pro se court reform lies. If any thought or effort is put into combining technology with the needs of pro se courts and litigants something truly revolutionary might emerge. Colin Rule, Director of online dispute resolution at eBay/PayPal, has written a book outlining the simple, but amazingly effective, eBay

240 See Stephan Lamdsman, The Growing Challenge of Pro Se Litigation, 13 LEWIS \& ClARK L. Rev. 439, 455-56 (2009) ("Probably the most popular option for addressing the pro se challenge is expansion of programs designed to teach the self-represented how to manage their own cases."). 
online dispute resolution system. ${ }^{241} \mathrm{~A}$ comparison between the online procedures versus what the typical pro se litigant faces in court is staggering. If pro se courts could ever be convinced to let technology loose the results would be exceptional: a simple, transparent court system aimed at assisting litigants in a considerate and efficient manner. Ask any poverty lawyer if any of those adjectives describe the courts where they practice and the answer will very likely be an emphatic no.

Interestingly, that is where the pro se court innovation concept truly departs into science fiction: imagine a world where there are special courts that are set up for the poor that operate so well that they are the envy of the wealthy who are still using a lawyer-driven model that persists from seventeenth-century England. The really crazy thing is that it is not only possible - if advocates for the poor could convince legislatures and courts that this approach would alleviate the pro se crisis, make more use of precious judicial resources, save money and (as a bonus) produce better, fairer outcomes - it may be probable.

\section{CONCLUSION}

Unfortunately that very possibility is exactly what may stand in the way. Lawyers and bar associations have powerful incentives to see pro se litigants flail in court. First, it convinces anyone who can even marginally afford a lawyer to try to get one before coming to court. Second, it makes civil Gideon look like a great solution - as per usual the solution to the struggle of the poor in America's courts is more lawyers. Lastly, it keeps the paying customers from drifting away on simple cases that they could possibly handle pro se like wills, divorces or bankruptcies. If

241 See Colin Rule, Online Dispute Resolution for Business (2002). 
poor people could cheaply and easily get a divorce it could take quite a toll on the paid divorce practice in this country.

Nevertheless, the seeds have been sewn. Unlike civil Gideon, which is an inherently conservative and backward-looking solution to a very real problem, pro se court reform has already begun and seems likely to accelerate. Now is the time for poverty lawyers and other advocates to throw their weight behind these efforts to help change the lives of the poor. Transforming the nature of American justice in the process is just the bonus package. 